\title{
Multi-methodical study of Early Modern Age archaeological glazed ceramics from Prague
}

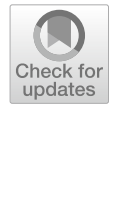

\author{
Alexandra Kloužková', Martina Kohoutková2* ${ }^{*}$, Mária Kolářová', Gabriela Blažková ${ }^{3}$ Radka Šefcư4,

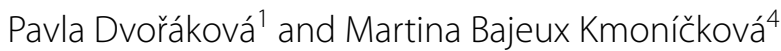

\begin{abstract}
A series of scientific methods (X-ray analyses, optical and electron microscopy, Raman spectroscopy and thermal analyses) was used to research the ceramic bodies and glazes of forty vessels from Renaissance Prague. The set of Early Modern Age archaeological glazed ceramics contained tableware, kitchenware and technical ceramics. The main aim was to characterise ceramic materials and glazes used over two centuries. Attention was also paid to the identification of defects and corrosion products of the glazes. The research was conducted with an emphasis on the context of the original use of the ceramic artefacts and the environment of the waste pits from which they were excavated. The archaeological finds include three technical ceramic vessels (a rectifier, a bowl and a jar), which together could have formed a distillation apparatus. Since these vessels represent a rare finding, they were subjected to a detailed investigation. Based on the similarity of ceramic bodies and glazes, it was proved that the three technical ceramic vessels were made in the same workshop and were parts of one distillation apparatus. The results of the performed analyses determined that the studied vessels were manufactured from raw materials with a high content of a plastic component and that the raw materials did not change significantly during the period from the 15th to 18th centuries. The firing temperature of most of the vessels did not exceed $1000^{\circ} \mathrm{C}$. It was proved that all the glazes were mediumor high-lead content glazes and were coloured with ionic pigments.
\end{abstract}

Keywords: Glazed ceramics, X-ray analysis, Raman spectroscopy, Thermal analysis, Early Modern Age, Prague

\section{Introduction}

Glazed ceramics are often studied from the perspective of decoration techniques, the macroscopic description of materials or the identification of pigments. Present-day research is also focused on identifying fabrication centres of workshops and how they developed; moreover, emphasis is placed on the manufacturing process or firing conditions. It is of course problematic to create an overall view or conclusion about glazed production in Central Europe because these sets are randomly examined. The study of Early Modern ceramic production in the Czech Republic, represented mainly by archaeological finds, is one of the rapidly developing topics. This study is one of

\footnotetext{
*Correspondence: martina.kohoutkova@vscht.cz

${ }^{2}$ Central Laboratories, University of Chemistry and Technology Prague,

Technická 5, 16628 Prague, Czech Republic

Full list of author information is available at the end of the article
}

the first using archaeometric data to evaluate Early Modern glazed ceramics from Prague. Archaeological finds from the waste pits of Prague's palaces were used for this purpose.

Early Modern ceramics production in Prague shows that Bohemian pottery production fully reflected the era's broader Central European trends in terms of shape and is comparable with assemblages of artefacts found in Germany [1-5], Austria [6-8], Switzerland [9-11], Hungary [12] and Poland [13, 14]. Any comparison with production from Slovakia is to some degree limited by the state of published assemblages. Generally speaking, in terms of ceramic production it can be said that during the Early Modern Age the Czech lands were part of developed Europe. The period from the 16th century to the first half of the 17th century is typified by the emergence and chiefly the increasing number of inner-glazed kitchenware and tableware. The main reason for the use

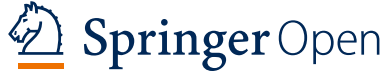

(c) The Author(s) 2020. This article is licensed under a Creative Commons Attribution 4.0 International License, which permits use, sharing adaptation, distribution and reproduction in any medium or format, as long as you give appropriate credit to the original author(s) and the source, provide a link to the Creative Commons licence, and indicate if changes were made. The images or other third party material in this article are included in the article's Creative Commons licence, unless indicated otherwise in a credit line to the material. If material is not included in the article's Creative Commons licence and your intended use is not permitted by statutory regulation or exceeds the permitted use, you will need to obtain permission directly from the copyright holder. To view a copy of this licence, visit http://creativeco mmons.org/licenses/by/4.0/. The Creative Commons Public Domain Dedication waiver (http://creativecommons.org/publicdomain/ zero/1.0/) applies to the data made available in this article, unless otherwise stated in a credit line to the data. 
of glazes in kitchenware was to prevent non-sintered ceramic bodies from absorbing water; the second reason was aesthetic. Starting in the last third of the 16th century, there was a gradual increase in pottery glazed on both sides-particularly among ceramic tableware. As in the rest of Europe, Bohemia witnessed an optimisation of ceramic forms. An individualisation of tableware is seen in the form of plates and other dishes intended for single servings. The artefact assemblages also feature numerous individual finds of ceramic items-primarily objects of a decorative character-that are not directly related to the consumption of food. A different example of the diversity of finds are technical ceramic vessels. The main aim of this work was to characterise ceramic bodies and glazes over two centuries and to find differences in the composition of both components (ceramic bodies and glazes). An important part of the study was focused on identification of the composition of glazes including colourants, their defects and corrosion products formed on the surface of glazes. Special attention was paid to investigation of technical ceramics with the aim, above all, to characterise

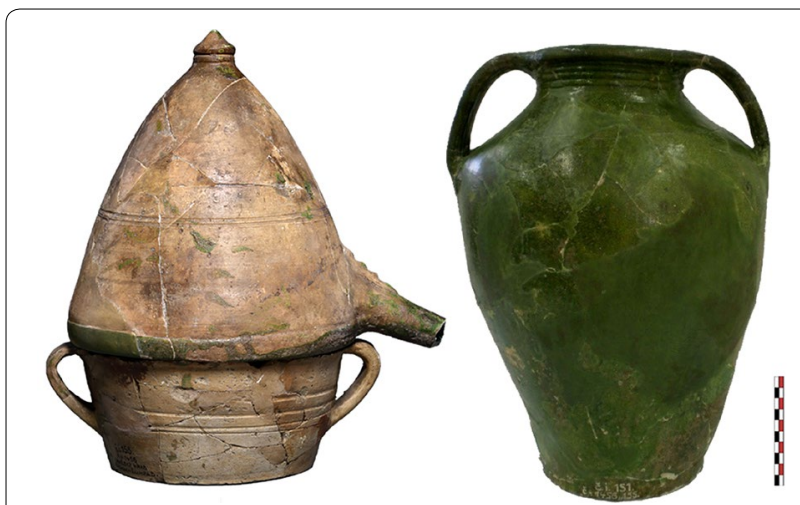

Fig. 1 Technical ceramic vessels: rectifier (no. 2) and bowl (no. 3) on the left and jar (no. 7) on the right their ceramic bodies and glazes and to ascertain whether these "chemical vessels" could be part of a single distillation apparatus (Fig. 1). An equally important part was the evaluation of historical glazes and their possible degradation. Scientific methods commonly used in archaeometry were used to meet the objectives-X-Ray analyses [15-17], optical microscopy and SEM technique in combination with X-Ray techniques [15, 18-24], thermal analyses [21, 22] and Raman spectroscopy [25-27]. The main advantage of used techniques when they are used for the study of rare and precious finds is that the same samples can be investigated by a combination of these techniques.

\section{Archaeological background}

This study is based on finds from waste pits from the Prague Castle complex and the Salm Palace in Prague's Hradčany (Fig. 2a) district. These are predominantly finds discovered during the initial period of archaeological research in the 1920s and early 1930s. The archaeological excavations in Salm Palace were undertaken in 2009 and 2010. Finds from all waste pits cover time periods of varying length from the second half of the 15th to the first half of the 18th century. Each of these finds was subjected to a detailed analysis [28], on the basis of which it was dated. Concerning dating, the main emphasis was placed on the wider spatial context of the waste pits, as the dating disputableness of such findings cannot be overlooked. From historical reports we know that waste pits were often, and repeatedly, jumbled up or partially removed [29-33]. It is possible that chronologically older objects could become a part of the younger finding context. Furthermore, in general, "luxury" items have been part of living culture much longer than ordinary consumer ceramics.

Of the original set of 783 complete or substantially reconstructed objects, 40 vessels were selected for the

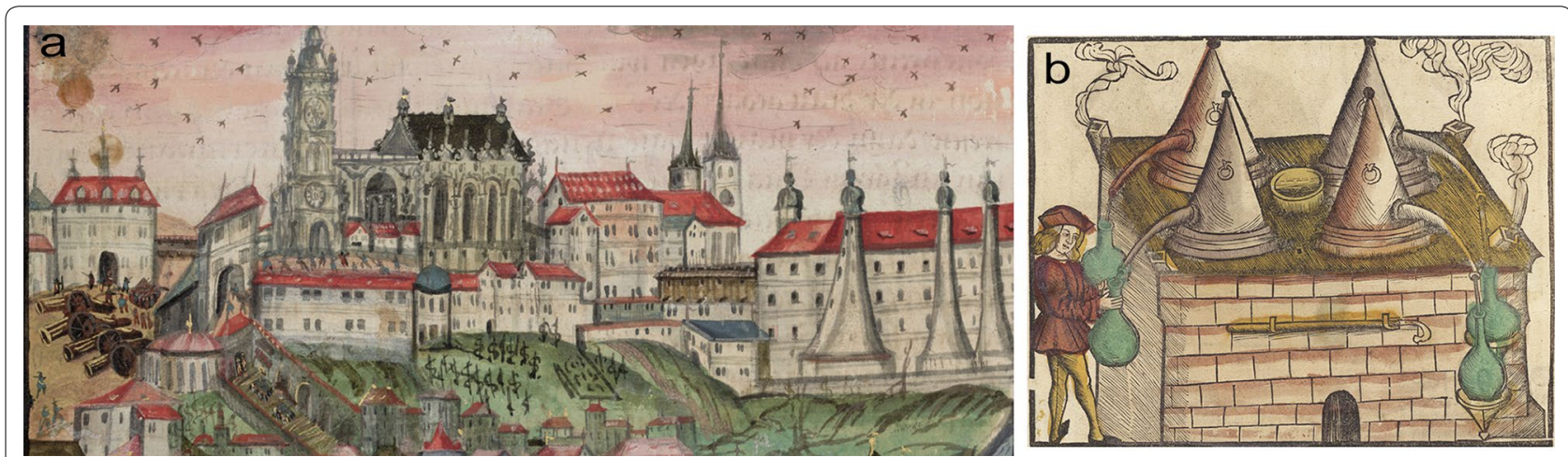

Fig. 2 a Illustration of the Hradčany district with Prague Castle, taken from the journal of Heinrich Hiesserle from Chodaw—The Prague Uprising on 15 th February 1611 [34]; b Liber de arte distillandi; Das buch der rechten kunst zu distilieren. Hieronymus Brunschwygk (1450-1512) [35] 
present study based on their typological context, shape and colour of glaze. The analysed set of samples comprises pots, pipkins, jugs, bowls, cups, a mug, a distillation lid and a flowerpot. The finds studied here were evaluated as a single set with emphasis on dating the individual vessels. In order to follow technological changes in ceramics production in time, namely at the turn of the Early Modern and Modern Ages in Prague, three time groups were defined. The division of the three-hundredyear-long section into these three time groups is based on the historical development of Prague and the Czech lands. In the first time period (1450-1550), the Late Medieval traditions of ceramic production clearly disappeared. Glazed ceramics appear in the assemblages of found artefacts, but even with regard to written evidence regarding the restriction of trade with glazes, glazed ceramics were probably not a common, widespread article [36]. The text of the fourth article of the statutes of the Potters' Guild of Prague Old Town from 1535 states that there is a ban on "trafficking" with what were most likely scarce glaze materials without the knowledge of both of Prague's older guilds (Old Town and New Town). Specifically, this applied to lead and iron ore. Another document providing evidence of problems with the supply of the raw materials required to produce glazes is a letter from 1551 , in which the Bohemian chamber of commerce approached the governor of the Krrivoklat region with a request to consider the possibility of mining lead ore near Castonice. There is a reference to potters' clay in the seventh article of the statues from 1535, in which the Prague pottery masters call on the city councillors to intervene on their behalf with the abbot of Strahov, who is preventing them from mining clay in the vicinity of the monastery. When this is taken in combination with instructions from 1590 associated with collecting customs duties for goods brought into Old Town over the Prague Bridge, in which there is mention of "clay, when the potters' black is being brought from the tenancy", it is highly likely that, in the 16th century, Prague potters were using, among other things, the grey to dark grey, layers of carbonised vegetation remnants and even the coal that came with the Cenomanian clay and claystone mined in the Petrín area. In the middle of the 16th century (1550-1650), there was an increase in ceramic production in Prague and glazed ceramics started to become widely available. Vessels fired in a reducing atmosphere make up only a single-digit percentage of finds. In this period, pottery from finely levigated clay with a slightly grainy fabric was made in Prague. The thin-walled vessels were turned on a fast-rotating potter's wheel. The ceramic assemblages are again dominated by barrel-shaped pots whose maximum width is located in the middle of the body. The majority of pots are glazed on the inside. Flat forms are represented by pans on a tripod. Another form is deep bowls. The European-wide phenomenon of this period is slip ware. This pottery was brought to Prague from nearby Beroun. The use of painted decoration appears most frequently on shallow bowls and jugs of all sizes. From the perspective of the pottery assortment, it can be stated that there was an expansion in the formal spectrum of production. These are mainly shallow bowls with a flanged rim; plates and cups newly appear. Undoubtedly, new Prague inhabitants coming from Italy, Spain and Germany participated in the development of crafts. In the second half of the 16th century, these national minorities formed a significant and relatively large population of Prague [37]. The beginning of the third period (1650-1750) is marked by the end of the Thirty Years' War (1648). In the second half of the 17th century there were significant changes in the power organization of Europe. These changes were then reflected in all areas of life.

So the oldest group of findings is dated to the second half of the 15th and the first half of the 16th century. The second time group is defined by the second half of the 16th century to the first half of the 17th century. The youngest group of findings then comes from the second half of the 17th to the first half of the 18th century.

In addition to the usual kitchenware and tableware, three vessels which can be described as technical ceramics were analysed-a distillation lid (no. 2, Fig. 1), a jar (no. 7, Fig. 1) and a rectification bowl (no. 3, Fig. 1). In the case of technical ceramics, glazing helped to increase the resistance of the surface (the rectification lid and the bowl were glazed on the inside only, while the jar was glazed on both sides). Ceramic vessels that may have formed a part of chemical equipment are rarely found in archaeological collections [2, 38-42]. Most often they come in the form of shards and only rarely can researchers analyse entire vessels. The above-mentioned findings of technical ceramics were discovered in Waste Pit B near the Old Provost House, the oldest residential building at Prague Castle located in the central part of the castle complex, adjoining St. Vitus Cathedral on the southwest. Historians identify the Old Provost House with the so-called Episcopal Court which was first mentioned in archival documents as early as the 11th century. The list of capitular houses from 1486 [43] states that the house was divided into two parts during this period, with the archbishop using the western part and the provost inhabiting the eastern part. The building was not reunified until 1660 [44].

During the rescue archaeological research in July 1925 , archaeologists explored Waste Pit B, which contained a rich collection of finds (ceramics, glass, iron) dating back to between 1450 and 1550 [45]. The assemblage was recorded [46]. Of the ceramic material found in the 
pit, 187 vessels were reconstructed, including three technical ceramic vessels which may have formed a distillation apparatus (Fig. 2b; Liber de arte distillandi). The fact that these objects were located (and most likely used) in an ecclesiastical building makes the whole assemblage particularly interesting. The vessels were reconstructed immediately after the completion of the archaeological research in the area. The method and process used for the reconstruction were thoroughly recorded. Along with keeping a detailed survey log, the researchers also recorded the laboratory examination of the vessels [4749]. The laboratory logs contain a detailed description of the daily process of the vessels' reconstruction and conservation, also specifying the binders used. In addition to these routine work records, the laboratory logs contain information about extraordinary events such as a doctor's visits, a funeral, the president's birthday [48] and the visit of an American archaeological expedition from Harvard University [49].

The set of artefacts from Waste Pit B is only one of nine assemblages from Prague Castle and Hradčany which were analysed in this study. Of 783 vessels, we focused on 40 (Table 1), which were chosen to help answer questions related to the way ceramics were produced during the Early Modern Age in Prague [50].

\section{Experimental procedure}

All analysed vessels come from waste pits from the Prague Castle complex and the Salm Palace. The preservation of all analysed objects in a similar environment is essential for their comparability. Samples for analysis were preferably selected from entire vessels of a similar type, in particular pipkins. The present investigation aims above all to characterise the ceramic bodies and glazes of 40 objects: 13 pipkins, 6 bowls, 10 pots, 3 cups, 2 plates and a jar, 2 jugs, a distillation lid, a flowerpot and a beer stein.

The studied finds were divided into three groups according to the probable time periods of their manufacture (Table 1). Detailed research was concentrated on three technical ceramic vessels, possibly parts of a unique distillation apparatus that was excavated from the different layers of Waste Pit B, and the same sequence of analysis was performed for all studied finds.

The average chemical composition of both the ceramic bodies and the glazes of all 40 vessels was determined by $\mathrm{X}$-ray fluorescence analysis (XRF). The advantage of this method is that the measurement is taken from a relatively large sample area (in this case an area $2.7 \mathrm{~cm}$ in diameter), which leads to the suppression of errors due to possible inhomogeneities. The chemical composition of the ceramic bodies was determined from powdered samples.
The samples were ground in an agate mortar and pressed into boric acid pots.

An ARL $9400 \mathrm{XP}^{+}$sequential WD-XRF spectrometer was used for the analysis and the acquired data were evaluated using the UniQuant 4 standardless software; the measured data were rounded based on the measurement error. The identified chemical compositions of all 40 vessels are listed in Table 2. The data for the rectification lid, the jar and the bowl were processed into PC diagrams (Fig. 3). Principal Component Analysis was performed using XLStat statistical software for Excel, which effectively summarized the XRF data according to quantitative variables (identified oxides). Subsequently, the XRF data were used to calculate normative minerals using the MINLITH program [51, 52]. This program was originally created for sedimentary rocks but it is also used to suggest the possible raw materials used for the production of historical ceramics. In this work, the program was used to obtain an idea of the possible presence of clay minerals in raw materials because meta-clays, which are usually present in ceramic bodies, cannot be detected by XRD [53, 54]. The calculated normative minerals and the input data for the evaluated "chemical" vessels are listed in Table 6. Chemical compositions of glazes were determined from the flat surfaces of ceramic shards using an Axios PANanalytical sequential XRF spectrometer; the data were evaluated using the Omnian standardless software. The glazes were analysed before and after chemical cleaning (using a $5 \%$ acid solution) of corrosion layers (Tables 4, 5). Mineralogical composition was identified by X-ray diffraction analysis (XRD) using an X'Pert PRO $\theta-\theta$ powder diffractometer and $\mathrm{CuK} \alpha$ radiation over the angular range of $5-70^{\circ}(2 \theta)$. Data evaluation was performed using the Panalytical High Score Plus 4.0 software package. Semi-quantitative analysis was performed using RIR (Reference Intensity Ratio) values from the PDF4+database of the HighScore Plus software. Mineralogical compositions of the glazes were determined from the surfaces of ceramic shards. In the case of ceramic body samples, powder samples were used for the analysis. Hydrothermally treated samples (after $100 \mathrm{~h}$ at $230{ }^{\circ} \mathrm{C}(2.77 \mathrm{MPa})$ in a Teflon lined autoclave $)$ were measured over the angular range of $2-15^{\circ} 2 \theta$ to examine for the presence of clay minerals.

Glaze colour was first evaluated visually and subsequently a spectrophotometric colouring measurement was used to interpret the effect of colouring oxides. The same method was employed to evaluate ceramic bodies in which the colour is influenced particularly by the presence of colouring compounds in raw materials (especially Fe and Ti compounds) and by firing conditions. The results of the colour measurement (using the CIE L*a*b* colour space) are presented in Table 7. A 
Table 1 List of the analysed set of samples with the specification of date, ware type and glaze colour

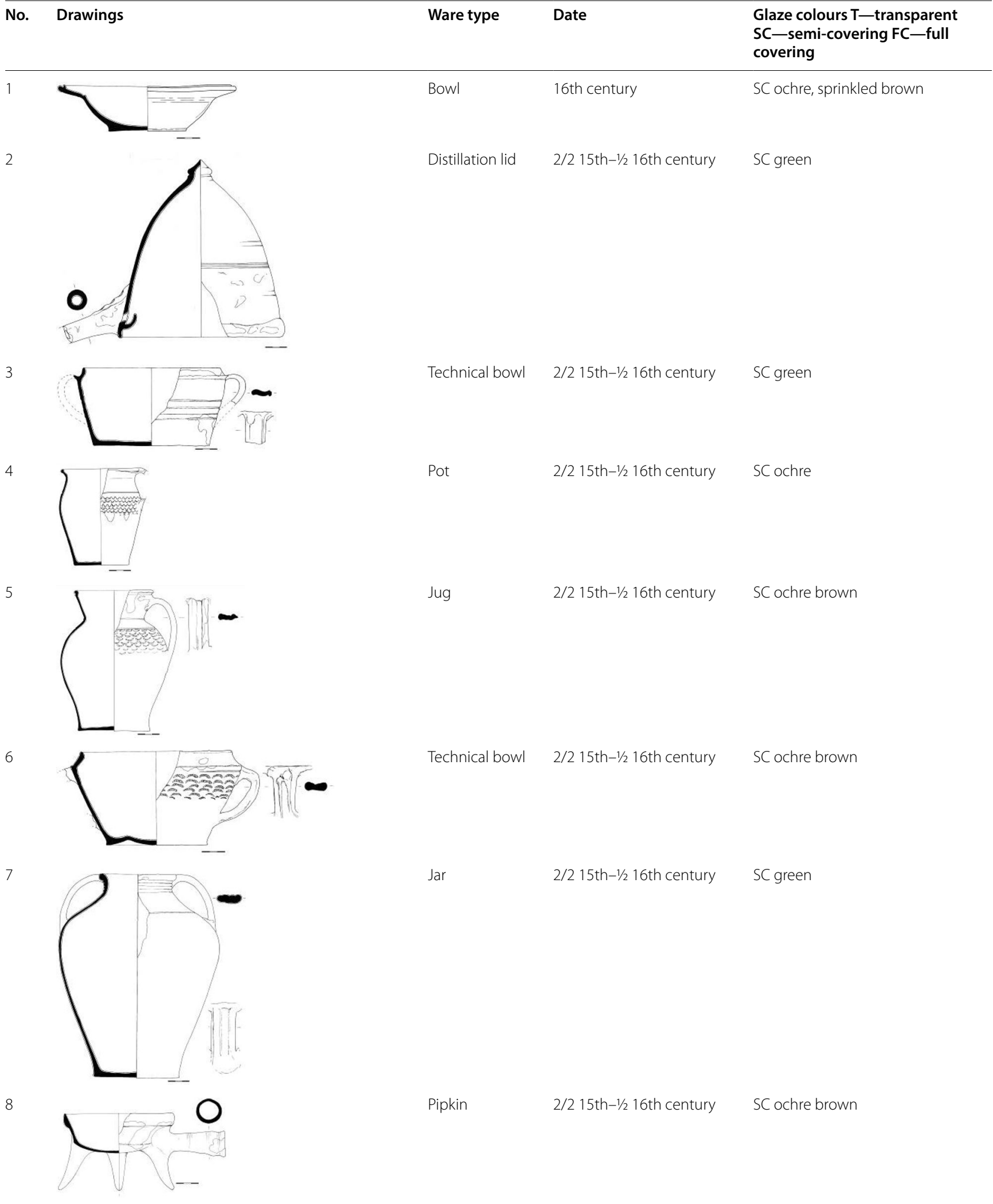


Table 1 (continued)

\begin{tabular}{|c|c|c|c|c|}
\hline No. & Drawings & Ware type & Date & $\begin{array}{l}\text { Glaze colours T-transparent } \\
\text { SC-semi-covering FC-full } \\
\text { covering }\end{array}$ \\
\hline 9 & 1 & Pot & $2 / 215$ th- $1 / 216$ th century & SC brown, ash \\
\hline 10 & & Pot & $2 / 215$ th-1/2 16th century & SC brown (to the green) \\
\hline 11 & & Pot & $2 / 215$ th- $1 / 216$ th century & T sprinkled brown \\
\hline 12 & & Pot & 16th century & SC green \\
\hline 13 & & Pot & $2 / 216$ th- $1 / 217$ th century & SC green \\
\hline 14 & & Small pot & $2 / 216$ th- $1 / 217$ th century & SC ochre yellow \\
\hline 15 & & Pot & $2 / 216$ th- $1 / 217$ th century & SC ochre brown \\
\hline 16 & & Bowl & $2 / 216$ th- $1 / 217$ th century & SC ochre brown \\
\hline 17 & & Pipkin & $2 / 216$ th- $1 / 217$ th century & SC ochre brown \\
\hline
\end{tabular}


Table 1 (continued)

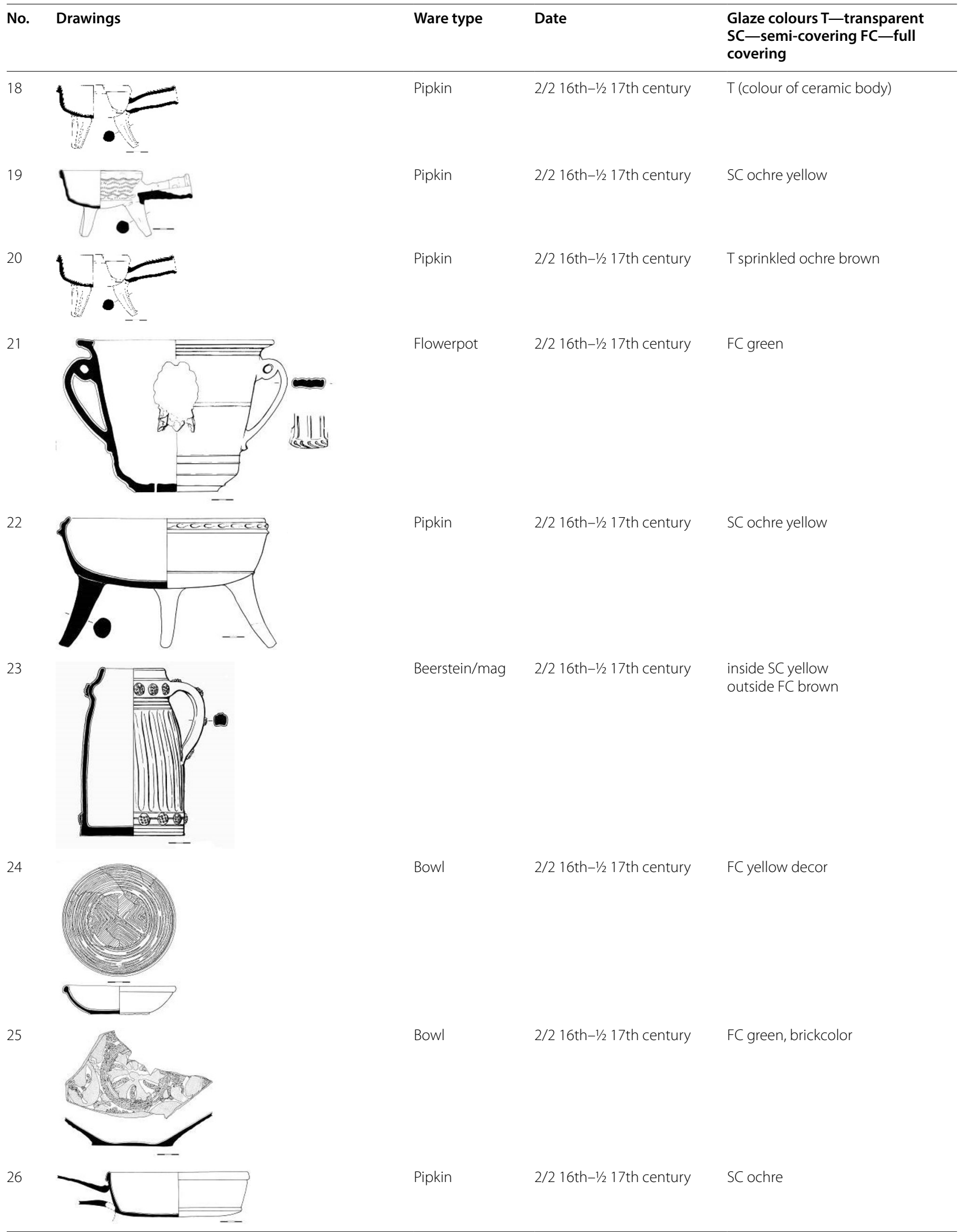


Table 1 (continued)

\begin{tabular}{|c|c|c|c|c|}
\hline No. & Drawings & Ware type & Date & $\begin{array}{l}\text { Glaze colours T-transparent } \\
\text { SC-semi-covering FC-full } \\
\text { covering }\end{array}$ \\
\hline 27 & & Pot & $2 / 217$ th-1/2 18th century & FC brown \\
\hline 28 & & Pipkin & $2 / 217$ th-1/2 18th century & SC green \\
\hline 29 & & Bowl & $2 / 217$ th- $-1 / 218$ th century & SC ochre, sprinkled green \\
\hline 30 & & Pipkin & $2 / 217$ th-1/2 18th century & FC brown-black \\
\hline 31 & & Pipkin & $2 / 217$ th-1/2 18th century & FC ochre-brown \\
\hline 32 & & Pot & $2 / 217$ th- $-1 / 218$ th century & FC orange-ochre \\
\hline 33 & & Pipkin & $2 / 217$ th- $-1 / 218$ th century & SC light green \\
\hline 34 & & Small bowl & $2 / 217$ th-1/2 18th century & FC green-black \\
\hline 35 & & Pipkin & $2 / 217$ th-1/2 18th century & FC brown-black \\
\hline 36 & & Pipkin & $2 / 217$ th- $-1 / 218$ th century & FC brown \\
\hline
\end{tabular}


Table 1 (continued)

\begin{tabular}{|c|c|c|c|c|}
\hline No. & Drawings & Ware type & Date & $\begin{array}{l}\text { Glaze colours T-transparent } \\
\text { SC-semi-covering FC-full } \\
\text { covering }\end{array}$ \\
\hline 37 & & Pot & 2/2 17th-1/3 18th century & Edge SC light green inside SC yellow \\
\hline 38 & & Pot & 2/2 17th-1/3 18th century & Edge FC brown inside SC yellow \\
\hline 39 & 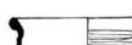 & Pot & $2 / 217$ th-1/3 18th century & Edge SC green inside SC yellow \\
\hline 40 & & Pot & 17th century & Edge SC green inside SC yellow \\
\hline
\end{tabular}

Datacolor Mercury 2000 reflection spectrophotometer, working in the visible spectrum range, was used for the measurement.

Parameters of the ceramic body materials (bulk density, weight absorption, apparent porosity and apparent density) were determined by weighing in water (before and after the sample was boiled for $2 \mathrm{~h}$, followed by storage in water for $24 \mathrm{~h}$ ). The data for the rectification lid, the jar and the bowl are presented in Table 6 below.

Thin sections of selected archaeological samples were examined using an optical microscope [55] in polarized light, with or without crossed polarizers. Mineralogical composition and the size and shape of grains in the samples were identified by optical microscopy (OM) using Olympus BX60 and BX51 optical microscopes and NISElements 2.03 software. Defects in the glazes were studied using an Olympus SZX9 stereomicroscope and an Olympus BX60 optical microscope.

Corrosion layers and pigments were evaluated using electron microscopy (TESCAN VEGA 3 LMU scanning electron microscope equipped with EDS analyser,
OXFORD Instruments INCA 350 and JEOL JSM-6460 LA equipped with EDS analyser). The samples for SEMEDS analyses were not polished due to the aim to analyse corrosion products on the surface of the glazes that could be destroyed by polishing.

The materials used for the glaze were identified by micro-Raman spectroscopy using a Nicolet DXR (Thermo Scientific) dispersive Raman microscope. The measurement principle used spot measurements taken directly on the particles in the glazes on the cross-section. Analyses were performed using a $780 \mathrm{~nm}$ diode laser, with maximum power of $5-7 \mathrm{~mW}$ and acquisition time of $5 \mathrm{~min}$. Measurements were taken in the range between 3300 and $50 \mathrm{~cm}^{-1}$. The spectral resolution was $4 \mathrm{~cm}^{-1}$. The laser was focused on the sample through $50 \times$ and $100 \times$ objective lenses. Raman spectra were processed with the Omnic 9.0 program.

In order to identify clay minerals, the samples of ceramic bodies of the three technical ceramic vessels were exposed to hydrothermal treatment in Teflon lined autoclaves at $230{ }^{\circ} \mathrm{C}(2.77 \mathrm{MPa})$ for $100 \mathrm{~h}$. 
Table 2 Chemical composition of the ceramic bodies from the studied set of finds (wt\%)

\begin{tabular}{|c|c|c|c|c|c|c|c|c|c|c|c|c|c|c|c|c|c|c|c|c|}
\hline mple & $\mathrm{SiO}_{2}$ & $\mathrm{Al}_{2} \mathrm{O}_{3}$ & $\mathrm{Fe}_{2} \mathrm{O}_{3}$ & $\mathrm{TiO}_{2}$ & $\mathrm{CaO}$ & $\mathrm{MgO}$ & $\mathrm{K}_{2} \mathrm{O}$ & $\mathrm{Na}_{2} \mathrm{O}$ & $\mathrm{P}_{2} \mathrm{O}_{5}$ & $\mathrm{SO}_{3} / \mathrm{S}$ & $\mathrm{Cl}$ & $\mathrm{V}_{2} \mathrm{O}_{5}$ & $\mathrm{Cr}_{2} \mathrm{O}_{3}$ & $\mathrm{MnO}$ & $\mathrm{CuO}$ & $\mathrm{ZnO}$ & $\mathrm{SrO}$ & $\mathrm{ZrO}_{2}$ & $\mathrm{BaO}$ & $\mathrm{PbO}$ \\
\hline 1 & 68 & 24 & 2.3 & 1 & 0.8 & 0.8 & 1.8 & 0.2 & 0.5 & 0.1 & 0.02 & 0.02 & 0.01 & 0.01 & 0 & 0.01 & 0.04 & 0 & 0.04 & 0.2 \\
\hline 2 & 67 & 24 & 3.2 & 1.2 & 0.9 & 0.8 & 1.6 & 0.2 & 0.7 & 0.1 & 0.01 & 0.02 & 0.01 & 0 & 0.02 & 0 & 0.03 & 0 & 0.02 & 0.2 \\
\hline 3 & 66 & 24 & 2.5 & 1.3 & 1.2 & 0.7 & & 0.3 & & 0.3 & 0.2 & 0 & 0.01 & 0 & 0.01 & 0.01 & 04 & 0.08 & .03 & 0.2 \\
\hline 4 & 68 & 25 & 1.8 & 1.8 & 0.6 & 0.6 & 1. & 0.2 & 0 & 0.03 & 0 & 0.02 & 0.01 & 0.01 & 0 & 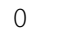 & .02 & 0.1 & .02 & .1 \\
\hline 5 & 70 & 19 & 2.7 & 0.9 & 1.2 & 1 & ? & 0.2 & & 0 & 0 & 0.02 & 0 & .01 & 0 & 0.02 & 0 & 0 & 02 & 3 \\
\hline 6 & 72 & 20 & 2 & 1 & 1 & 0.7 & 2 & 0.5 & 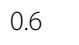 & 0.1 & 0.04 & 0 & 0 & 0.02 & 0 & 0 & .03 & 0.06 & 0.03 & .1 \\
\hline 7 & 70 & 22 & 2.3 & 1.1 & 0.7 & 0.9 & 1.7 & 0.2 & 0.4 & 0.2 & 0 & 0.02 & 0.01 & 0.01 & 0.03 & 0.01 & 0.03 & 0 & 0.01 & 0.6 \\
\hline 8 & 69 & 23 & 2.8 & 1.3 & 0.8 & 0.8 & 1.6 & 0.2 & 0.3 & 0.1 & 0 & 0.02 & 0.02 & 0.01 & 0 & 0.01 & 0.03 & 0.1 & .02 & 0.4 \\
\hline 9 & 69 & 21 & 2.5 & 1 & 1.2 & 0.9 & 1.9 & 0.2 & 1 & 0.1 & 0 & 0.02 & 0.01 & 0.01 & 0 & 0.01 & 0.04 & 0 & 0.02 & 1 \\
\hline 10 & 72 & 19 & 2. & 0.9 & 1 & 0.9 & 1 & 0.1 & 0.9 & 0.2 & 0 & 0.01 & 0.01 & 0.01 & 0 & 0.02 & 0 & 0 & .03 & 0.2 \\
\hline 1 & 71 & 20 & 3. & 0.8 & 1.4 & 1.1 & 1.0 & 0.2 & & 0.1 & 0 & 0.02 & 0.01 & 0.03 & 0 & 0.02 & - & 0 & .02 & 0.1 \\
\hline 12 & 72 & 19 & 2.7 & 0.8 & 1.1 & 1 & 2 & 0.2 & 0.7 & 0.1 & 0.01 & 0.02 & 0.01 & 0.02 & 0.01 & 0.01 & 0 & 0 & .02 & 0.7 \\
\hline 13 & 67 & 22 & 5 & 1 & 0.6 & 1.2 & 2.5 & 0.2 & 0 & 0.1 & 0 & 0.03 & 1 & 1 & 0.01 & .02 & 0 & .04 & .04 & .6 \\
\hline 14 & 64 & 29 & 1.7 & 1.4 & 0.5 & 0.6 & 1.4 & 0.1 & 0.2 & 0.1 & 0 & 0.02 & 0.02 & 0 & 0 & 0.02 & 0 & 0.1 & 0.02 & 0.5 \\
\hline 15 & 65 & 28 & 2.5 & 1.5 & 0.8 & 0.6 & 1 & 0.2 & 0.2 & 0.1 & 0 & 0.02 & 0.02 & 0.01 & 0 & 0 & 0.01 & 0.1 & 0.01 & 0.2 \\
\hline 16 & 58 & 32 & 2.8 & 2.8 & 1.1 & 0.4 & 1.3 & 0.2 & 0.6 & 0.1 & 0 & 0.03 & 0.03 & 0.02 & 0 & 0.01 & 0.01 & 0.1 & 0.03 & 0.2 \\
\hline 17 & 60 & 30 & 2.6 & 1.4 & 1.2 & 0.6 & 1.6 & 0.2 & 0.4 & 0.01 & 0 & 0.02 & 0.02 & 0.03 & 0 & 0.01 & 0.01 & 0 & 0.02 & 1.1 \\
\hline 18 & 66 & 23 & 4 & 1.1 & 0.8 & 1.1 & 2. & 0. & 0 & 0.03 & & 0.03 & 0 & 0 & 0 & 1 & 01 & 0.04 & .04 & .2 \\
\hline 19 & 62 & 29 & 2.3 & 1.4 & 1.7 & 0.6 & 1.3 & 0.2 & 0.03 & 0.1 & 0.03 & 0.02 & 0.02 & 0.02 & 0 & 0 & 0.01 & 0.1 & 0.02 & 0.1 \\
\hline 20 & 64 & 27 & 2 & 1.3 & 1 & 0.9 & 2.1 & 0.2 & 0.7 & 0.1 & 0.02 & 0.03 & 0.02 & 0.2 & 0.01 & 0 & 0.02 & 0.01 & 0.03 & 0.6 \\
\hline 21 & 65 & 26 & 2.9 & 1.3 & 1 & 0.7 & 1.3 & 0.2 & 0.5 & 0.2 & 0.1 & 0.02 & 0.02 & 0.01 & 0.01 & 0.03 & 0.02 & 0 & 0.02 & 0.3 \\
\hline 22 & 62 & 29 & 2.2 & 1.6 & 1.8 & 0.5 & 0.8 & 0.1 & 0.2 & 0.1 & 0 & 0.03 & 0.02 & 0.01 & 0 & 0.01 & 0 & & .02 & 1 \\
\hline 23 & 64 & 27 & 2.6 & 1.5 & 1 & 0.5 & 1 & 0.2 & 0.5 & 0.3 & 0.03 & 0.03 & 0.02 & 0.02 & 0.01 & 0.02 & 0.01 & 0.1 & 0.02 & 1.3 \\
\hline 24 & 65 & 22 & 5 & 1 & 0.6 & 1.1 & 2.8 & 0.2 & 0.3 & 1.1 & 0.01 & 0.02 & 0.01 & 0.01 & 0.5 & 0.02 & 0 & 0.04 & 0.02 & 0.1 \\
\hline 25 & 57 & 26 & 1.6 & 1.2 & 0.4 & 0.5 & 2.9 & 0.2 & 0.2 & 0.1 & 0 & 0.02 & 0.01 & 0.01 & 0 & 0.02 & 0 & 0 & 0 & 0.1 \\
\hline 26 & 62 & 29 & 2.4 & 1.4 & 0.9 & 0.7 & 1.3 & 0.2 & 0.1 & 0.4 & 0 & 0.03 & 0.02 & 0.02 & 0 & 0.01 & 0 & 0 & 0.02 & 1.1 \\
\hline 27 & 64 & 24 & 5 & 0.7 & 0.9 & 0.8 & 2. & 0.3 & & 1.6 & 0 & 0 & 0 & 0.01 & 0 & 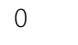 & .02 & 0.03 & 0.03 & 0.2 \\
\hline 28 & 64 & 26 & 2 & 2.4 & 0.5 & 1 & 2.6 & 0.2 & 0.1 & 0.02 & 0 & 0 & 0.02 & 0 & 0.01 & 0.01 & 0.02 & 0.1 & 0.03 & 0.6 \\
\hline 29 & 62 & 28 & 2.7 & 0.9 & 0.8 & 0.8 & 2.9 & 1.1 & 0.2 & 0.3 & 0.02 & 0.01 & 0.02 & 0.01 & 0 & 0.02 & 0 & 0.1 & 0.1 & 0.2 \\
\hline 30 & 64 & 27 & 2.8 & 1.7 & 0.7 & 0.8 & 2.6 & 0.3 & 0.1 & 0.4 & 0 & 0.04 & 0.03 & 0.01 & 0 & 0 & 0.03 & 0 & 0.04 & 0.2 \\
\hline 31 & 61 & 30 & 2.3 & 2.5 & 1 & 0.4 & 1.3 & 0.2 & 0.1 & 0.7 & 0 & 0 & 0.03 & 0 & 0 & 0.01 & 0 & 0.1 & 0.02 & 0.6 \\
\hline 32 & 61 & 32 & 2.8 & 1.7 & 0.7 & 0.4 & 0.7 & 0.3 & 0.1 & 0.1 & 0 & 0.03 & 0.02 & 0.01 & 0 & 0 & 0 & 0.1 & 0 & 0.2 \\
\hline 33 & 63 & 27 & 1.4 & 1.7 & 0.7 & 0.8 & 2.4 & 0.2 & 0.1 & 0.3 & 0 & 0.03 & 0.03 & 0 & 0 & 0 & 0.03 & 0 & 0.03 & 1.7 \\
\hline 34 & 61 & 30 & 1.5 & 2.1 & 0.5 & 0.8 & 2.8 & 0.3 & 0.1 & 0.3 & 0 & 0 & 0.04 & 0 & 0.02 & 0 & 0.03 & 0 & 0.03 & 0.6 \\
\hline 35 & 69 & 23 & 1.8 & 1.3 & 0.4 & 0.6 & 2.1 & 0.4 & 0.1 & 0.4 & 0.01 & 0.02 & 0 & 0 & 0.02 & 0 & 0.01 & 0.1 & 0.02 & 0.8 \\
\hline 36 & 61 & 25 & 5.4 & 0.9 & 2.5 & 1.1 & 2.5 & 0.7 & 0.1 & 0.2 & 0.03 & 0.02 & 0.01 & 0 & 0 & 0.04 & 0.01 & 0.1 & 0 & 0.8 \\
\hline 37 & 63 & 22 & 4 & 4 & 1.1 & 0.7 & 1.8 & 0.2 & 1.8 & 0.2 & 0 & 0.04 & 0.1 & 0.03 & 0 & 0.04 & 0.05 & 0.1 & 0 & 1.2 \\
\hline 38 & 60 & 32 & 2.2 & 1.7 & 1 & 0.5 & 1.1 & 0.2 & 1 & 0.1 & 0 & 0 & 0.02 & 0.6 & 0 & 0.02 & 0.01 & 0.02 & 0 & 0.02 \\
\hline 39 & 60 & 32 & 1.4 & 3.2 & 0.8 & 0.4 & 0.5 & 0.3 & 1.5 & 0.1 & 0 & 0 & 0.03 & 0.01 & 0.01 & 0.02 & 0.01 & 0.04 & 0 & 0.1 \\
\hline 40 & 57 & 34 & 2 & 3 & 1.2 & 0.5 & 1 & 0.9 & 0.8 & 0.1 & 0.02 & 0 & 0.02 & 0.02 & 0.01 & 0.02 & 0.01 & 0.04 & 0 & 0.15 \\
\hline
\end{tabular}

The mineralogical compositions of the hydrothermally treated ceramic bodies were determined by means of thermal analyses in TG-DTA mode using an STA LINSEIS PT1600/1750 ${ }^{\circ} \mathrm{C}$ HiRes analyser. The measurements were carried out on fine powders in the temperature range $\mathrm{RT}-1000{ }^{\circ} \mathrm{C}$ with the heating range $10{ }^{\circ} \mathrm{Cmin}^{-1}$ in helium flow. Released gases $\left(\mathrm{H}_{2} \mathrm{O}\right.$ and $\left.\mathrm{CO}_{2}\right)$ were measured by a Pfeiffer Vacuum OmniStar mass spectrometer in the range of $300 \mathrm{AMU}$.

\section{Results}

Evaluation of the ceramic bodies

Table 2 presents the chemical composition of the ceramic bodies (determined by XRF) in the form of 

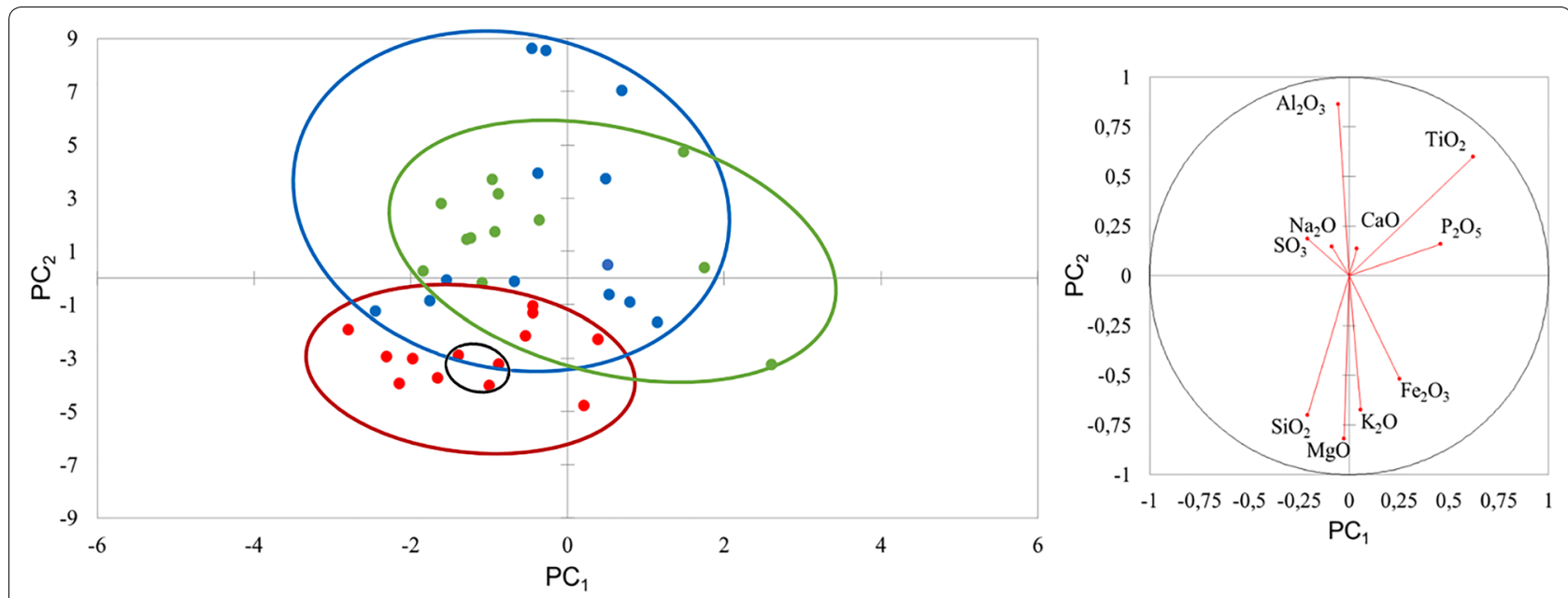

Fig. 3 Principal component biplot of the XRF data for the ceramic bodies of all analysed archaeological finds from Prague Castle waste pits: the principal component biplot showing the samples divided into groups. Coloured points and circles indicate the date of origin: red-the second half of the 15th century to the first half of the 16th century, green-the second half of the 16th century to the first half of the 17th century, blue-the second half of the 17 th century to the first half of the 18th century. The black circle indicates samples of the parts of the distillation apparatus

oxides. Figure 3 shows the principal components of the ceramic bodies of all the analysed archaeological finds and their distribution into groups by date of origin.

The mineralogical compositions obtained by an evaluation of diffraction patterns of all samples of the analysed collection are shown in Table 3.

The mineralogical compositions were also studied by optical microscopy. Thin section preparation is a destructive process and therefore could not be applied to all ceramic findings. 15 thin sections were prepared from the studied vessels, with each group represented by 5 thin sections. All evaluated samples from the oldest group of findings (nos. 2, 3, 5, 7 and 8) and one (no. 19) from the second time group-the second half of the 16th century to the first half of the 17th centurycontained significantly bimodal temper in the form of quartz and solitary feldspars. The relative abundance of inclusions in the samples, estimated by using comparative charts, is c. $10-20 \%$. Inclusions in fine fractions $(30-150 \mu \mathrm{m})$ are sub-angular to sub-round. Big inclusions of feldspar temper (Fig. 4a) are rare (under $1 \%)$. The matrix is non-calcareous with fine inclusions (about $10 \mu \mathrm{m}$ in diameter) of quartz and muscovite and contains elongate voids. Some samples from the second time group (nos. 20, 21 and 22) and some from the youngest group of findings (nos. 29 and 35) show an optically active non-calcareous matrix rich in mica grains, and a sporadic mixing of two types of clays was identified (Fig. 4b). Most samples from the youngest group (nos. 27, 31 and 36) and one from the second time group (no. 18) show a relative abundance of inclusions (20\%) and no big inclusions of temper (Fig. 4c) and iron pigmentation (nos. 18, 27, 36) in the non-calcareous matrix.

\section{Evaluation of the glazes}

The chemical compositions of the glazed surfaces were measured before and after the removal of corrosion crusts (Tables 4, 5, Figs. 5, 6). The analysed finds had been cleaned and washed with water during the first restoration in the 1920s, but the corrosion crusts were left.

Most of the degraded vessels from the set of studied samples were parts of a distillation apparatus (rectification bowl, distillation lid and collection jar), which is related to their use (Fig. 5, the red squares on the right of the chart). XRD analyses determined that the majority of the glazes (77\%) did not contain any crystalline phase and that the other glazes contained mainly quartz and rarely cassiterite.

\section{Distillation apparatus}

The chemical composition of the three technical ceramic vessels (rectification lid no. 2, jar no. 7 and bowl no. 3) is shown in Fig. 2 (black circle) and Table 3 (in green). Figure 7 shows XRD patterns of the ceramic body of the bowl and the detail of the XRD pattern of the same sample after hydrothermal loading. XRD analyses of the hydrothermally treated sample demonstrates the presence of montmorillonite and kaolinite in the sample.

The normative minerals (Table 6) characterizing the probable raw material mixtures used for the vessels (with the simplifications mentioned in the Experimental Procedure) were calculated using the chemical composition determined by XRF. The table is supplemented with 
Table 3 Mineralogical composition of the ceramic bodies from the studied set of finds

\begin{tabular}{|c|c|c|c|c|c|c|c|c|}
\hline \multirow[t]{2}{*}{ Sample } & \multicolumn{8}{|c|}{ Mineral (wt\%) } \\
\hline & Quartz & Anatase & Rutile & $\begin{array}{l}\text { Muscovite/ } \\
\text { biotite }\end{array}$ & K feldspars & Hematite & Mullite & $\begin{array}{l}\mathrm{Ca}, \mathrm{Na} \\
\text { feldspars }\end{array}$ \\
\hline 1 & $>85$ & $<3$ & & & $<5$ & & $<5$ & \\
\hline 2 & $>80$ & $<3$ & & $<5$ & $<5$ & & & $<5$ \\
\hline 3 & $>75$ & $<3$ & & $<10$ & $<5$ & & & $<5$ \\
\hline 4 & $>85$ & $<3$ & & & $<3$ & & $<5$ & \\
\hline 5 & $>80$ & $<3$ & & & $<5$ & & $<5$ & \\
\hline 6 & $>80$ & $<3$ & & & $<10$ & & & $<5$ \\
\hline 7 & $>80$ & $<3$ & & & $<3$ & & $<3$ & \\
\hline 8 & $>85$ & $<5$ & & $<5$ & $<3$ & $<3$ & & \\
\hline 9 & $>80$ & $<3$ & & & $<5$ & & $<5$ & \\
\hline 10 & $>80$ & $<3$ & & & $<5$ & & & \\
\hline 11 & $>85$ & & & & $<5$ & $<3$ & $<5$ & \\
\hline 12 & $>85$ & & & & $<3$ & & $<5$ & \\
\hline 13 & $>75$ & $<3$ & & $<10$ & $<3$ & $<5$ & & \\
\hline 14 & $>85$ & $<5$ & & & $<3$ & & $<3$ & \\
\hline 15 & $>80$ & $<5$ & & & $<3$ & & $<5$ & \\
\hline 16 & $>80$ & $<5$ & & $<5$ & $<3$ & $<3$ & & \\
\hline 17 & $>75$ & $<5$ & & & $<3$ & & $<10$ & \\
\hline 18 & $>80$ & $<3$ & & $<5$ & $<3$ & $<5$ & & \\
\hline 19 & $>80$ & $<5$ & & $<5$ & $<3$ & & $<5$ & \\
\hline 20 & $>80$ & $<5$ & & $<10$ & & & & \\
\hline 21 & $>75$ & $<5$ & & $<10$ & $<3$ & $<3$ & & \\
\hline 22 & $>80$ & $<5$ & & $<5$ & $<3$ & & $<3$ & \\
\hline 23 & $>80$ & $<3$ & & & $<3$ & & $<10$ & \\
\hline 24 & $>70$ & $<3$ & & $<10$ & $<3$ & $<5$ & & \\
\hline 25 & $>70$ & $<5$ & & $<10$ & $<10$ & & $<3$ & \\
\hline 26 & $>80$ & $<5$ & & & $<3$ & & $<10$ & \\
\hline 27 & $>80$ & $<3$ & & $<5$ & $<5$ & $<3$ & & \\
\hline 28 & $>80$ & $<5$ & & $<5$ & $<5$ & & & \\
\hline 29 & $>70$ & $<3$ & & $<10$ & $<10$ & & & $<10$ \\
\hline 30 & $>80$ & $<5$ & & & $<3$ & & $<5$ & \\
\hline 31 & $>80$ & $<5$ & & $<5$ & $<3$ & + & & \\
\hline 32 & $>90$ & $<3$ & + & & & & $<5$ & \\
\hline 33 & $>80$ & $<5$ & & $<3$ & $<3$ & & $<5$ & \\
\hline 34 & $>80$ & $<5$ & & $<3$ & & & $<5$ & \\
\hline 35 & $>85$ & $<5$ & & $<5$ & & & & \\
\hline 36 & $>75$ & & & & $<10$ & $<5$ & & $<5$ \\
\hline 37 & $>85$ & $<5$ & + & & $<5$ & & + & \\
\hline 38 & $>90$ & $<5$ & + & & $<3$ & & & \\
\hline 39 & $>90$ & $<5$ & $<3$ & & & & $<3$ & \\
\hline 40 & $>80$ & $<3$ & + & & & & $<10$ & \\
\hline
\end{tabular}

parameters of the ceramic bodies that characterise the degree of sintering of ceramics.

Optical microscopy was used to study the microstructure of selected vessels by evaluating thin sections (Fig. 8). Figure 8a shows the glaze layer on bowl no. 3 with a thickness ranging between 240 and $0 \mu \mathrm{m}$ and signs of corrosion. Figure 8c, d show very slightly an "optically active" matrix with mica plates. Figure $8 \mathrm{~b}$ represents the isometric grain of plagioclase feldspar, also detected by XRD analysis (Table 3). 


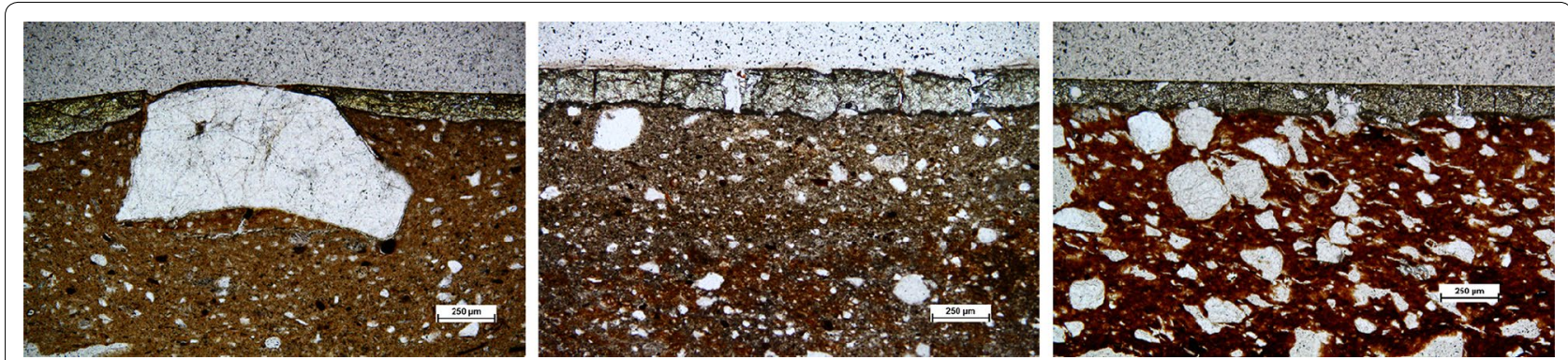

Fig. 4 OM images of thin sections: a sample of jug no. 5, b sample of pipkin no. 22, c sample of pipkin no. 36

The meta-clays contained in the ceramic bodies became rehydrated/rehydroxylated as a result of their use and subsequent preservation in a waste pit. In the course of thermal analysis, their dehydration/dehydroxylation was monitored during the heat load [56, 57]. Figure 9 shows the TG-DTA curves illustrating the dehydration (50-250 ${ }^{\circ} \mathrm{C}$ ) and dehydroxylation (350$520{ }^{\circ} \mathrm{C}$ ) processes in the samples.

The chemical composition of the glazes of the three technical ceramic vessels before and after the surfaces were cleaned was determined by XRF analysis (Figs. 5, 6 ). The chemical composition converted to molar percentage (main components) and the colouring of glazes, including CIE $\mathrm{L}^{*} \mathrm{a}^{*}$ and $\mathrm{b} *$ values, are listed in Table 7.

The presence of corrosion products in the form of inorganic acid salts was confirmed by XRF analysis. The chemical composition of the surface of the glaze was measured before and after cleaning. It is evident that corrosion products were partially removed during purification as the content of $\mathrm{P}$ and $\mathrm{Ca}$ decreased significantly and conversely the content of $\mathrm{Si}$ increased. The molar percentages were calculated from values measured by XRF (Table 7). The conversion to molar percentages is performed mainly to identify the function of lead oxide in the structure-whether it is involved in the formation of a glass mesh or not. Changes of conditions (waste pits, deposits) had a significant effect on the process of degradation and the kinetics of the corrosion process. Crystallization of corrosion products on the surface of the glazes enhanced the further leaching of cations from the glassy network [58].

Figure 10a, b show SEM images of green glazes with a thickness ranging between 40 and $130 \mu \mathrm{m}$ and signs of degradation (especially cracking). In the case of jar no. 7 , the inside glaze layer is about $100 \mu \mathrm{m}$ thick (Fig. 10a) whereas the thickness of the outside glaze layer fluctuates around $60 \mu \mathrm{m}$. The corrosion products were identified using XRD as lead and calcium phosphates. Scanning electron microscopy also revealed the presence of quartz grains directly in the glaze layers (Fig. 10c).
The chemical composition of the glazes of the technical ceramic vessels was also determined using EDS analysis (Table 8), which demonstrated that the glazes with high lead content were coloured with ionic colourants (largely $\mathrm{Cu}$ ). Figure $10 \mathrm{e}$ shows the corrosion crust in the form of calcium and lead phosphates, also detected using XRD. Chloride corrosion products were identified in the sample from the jar (Fig. 10f). Sulphide corrosion products were detected in the crack above the quartz grain within the glaze of the bowl (Fig. 10g).

The green colouring in the lead glazes resulted from the combination of ionic colours-particularly $\mathrm{Cu}$ and Fe oxides. The glazes also contain a very small amount of Sb oxide (Tables 5, 7). SEM analysis also identified $0.5 \mathrm{wt} \%$ of $\mathrm{Sn}$ in the glaze of the bowl. Micro-Raman spectroscopy played an important part in studying the material composition of the glazes. The signal at 468$465 \mathrm{~cm}^{-1}$, associated with peaks at 201-204, 264-267, $356-358$ and $396-398 \mathrm{~cm}^{-1}$, is due to the presence of quartz, $\mathrm{SiO}_{2}$ (Fig. 11), which was detected in all the investigated samples from the lid, the jar and the bowls [59]. All samples show a strong peak at $146 \mathrm{~cm}^{-1}$ and weak peaks at 205, 394, 514 and $637 \mathrm{~cm}^{-1}$, attributed to the presence of titanium oxide-anatase. Characteristic bands of rutile were not found. Raman signals of yellow grains in green glazes at $130-132 \mathrm{~cm}^{-1}$ may be attributed to $\mathrm{Pb}-\mathrm{Sn}$-based compounds known as leadtin yellow $\left(\mathrm{Pb}_{2} \mathrm{SnO}_{4}\right.$ or $\left.\mathrm{PbSn}_{1-\mathrm{x}} \mathrm{SixO}_{3}\right)$ or to $\mathrm{Pb}-\mathrm{Sb}$ based compounds known as Naples yellow $\left(\mathrm{Pb}\left(\mathrm{SbO}_{3}\right)_{2}\right.$ or $\left.\mathrm{Pb}\left(\mathrm{SbO}_{4}\right)_{2}\right)$ [27, 60]. The strongest peak characteristic of lead-tin yellow is found at $130-132 \mathrm{~cm}^{-1}$. The identification of Naples yellow is complicated due to the presence of anatase, as their principal peaks (approximately $145 \mathrm{~cm}^{-1}$ ) overlap. In all the samples, the spectra of the green glaze grains show a broad band around 900-970 $\mathrm{cm}^{-1}$. The presence of copper in the green lead glazes was not confirmed by Raman spectroscopy, as copper can be dispersed in ionic form with no specific vibration in Raman spectra [61]. 
Table 4 Chemical composition of the glazes of all studied finds analysed before the chemical cleaning of corrosion layers (wt\%)

\begin{tabular}{|c|c|c|c|c|c|c|c|c|c|c|c|c|c|c|c|c|c|c|c|c|}
\hline Sample & $\mathrm{SiO}_{2}$ & $\mathrm{Al}_{2} \mathrm{O}_{3}$ & $\mathrm{Fe}_{2} \mathrm{O}_{3}$ & $\mathrm{TiO}_{2}$ & $\mathrm{CaO}$ & $\mathrm{MgO}$ & $\mathrm{K}_{2} \mathrm{O}$ & $\mathrm{Na}_{2} \mathrm{O}$ & $\mathrm{P}_{2} \mathrm{O}_{5}$ & $\mathrm{SO}_{3}$ & $\mathrm{Cl}$ & $\mathrm{MnO}$ & $\mathrm{CuO}$ & $\mathrm{ZnO}$ & $\mathrm{ZrO}_{2}$ & $\mathrm{BaO}$ & $\mathrm{PbO}$ & $\mathrm{SnO}_{2}$ & $\mathrm{Sb}_{2} \mathrm{O}_{3}$ & $\mathrm{Bi}_{2} \mathrm{O}_{3}$ \\
\hline $1 \mathrm{G}$ & 22 & 6 & 5 & 0 & 4 & 0.3 & 0.4 & 0.5 & 7 & 1 & 0 & 0 & 0 & 2 & 0 & 0 & 52 & 0 & 0 & 0 \\
\hline $2 G$ & 42 & 6.9 & 1.1 & 0.5 & 3.5 & 0.3 & 2 & 0.6 & 3.9 & 1.8 & 0.7 & 0 & 2.2 & 0.01 & 0.03 & 0.1 & 34 & 0 & 0.2 & 0 \\
\hline $3 G$ & 30 & 2.4 & 1.1 & 0.3 & 1.4 & 0.3 & 0.4 & 0.2 & 0.3 & 4.2 & 2.8 & 0.04 & 2.5 & 0.04 & 0 & 1.5 & 52 & 0 & 0.1 & 0 \\
\hline $4 \mathrm{G}$ & 8 & 3 & 1 & 0 & 52 & 0.8 & 0.2 & 1 & 28 & 3 & 0.3 & 0 & 0 & 0.2 & 0.1 & 0 & 4 & 0 & 0 & 0 \\
\hline $5 \mathrm{G}$ & 24 & 3 & 6 & 0 & 3 & 0.3 & 1 & 1 & 8 & 1 & 1 & 0 & 0 & 1 & 0 & 0 & 51 & 0 & 0 & 0.2 \\
\hline $6 \mathrm{G}$ & 36 & 1 & 6 & 0 & 18 & 0.3 & 0.4 & 1 & 19 & 1 & 3 & 0 & 0 & 4 & 0 & 0 & 40 & 0 & 0 & 0 \\
\hline $7 G$ & 38 & 4.8 & 0.9 & 0.3 & 2.7 & 0.8 & 1.7 & 1 & 3.5 & 2.3 & 1.1 & 0 & 3.5 & 0.02 & 0 & 0.1 & 39 & 0 & 0.2 & 0.1 \\
\hline $8 \mathrm{G}$ & 23 & 3 & 5 & 0 & 0.3 & 0.3 & 0.3 & 0.2 & 0.4 & 0.5 & 0.1 & 0 & 0 & 1 & 0 & 0 & 66 & 0 & 0 & 0 \\
\hline $9 \mathrm{G}$ & 16 & 9 & 10 & 0 & 14 & 0.4 & 0.2 & 0.3 & 16 & 1 & 1 & 0 & 0 & 0.3 & 0 & 0 & 46 & 0 & 0 & 0 \\
\hline $10 \mathrm{G}$ & 26 & 5 & 1 & 0 & 2 & 0.8 & 1 & 0.4 & 2 & 0.3 & 0 & 0 & 2 & 0 & 0 & 0 & 61 & 0 & 0 & 0 \\
\hline $11 \mathrm{G}$ & 23 & 4 & 5 & 0 & 13 & 0.6 & 1 & 1 & 10 & 1 & 0.5 & 0 & 0 & 0 & 0 & 0 & 43 & 0 & 0 & 0 \\
\hline $12 \mathrm{G}$ & 13 & 4 & 4 & 2 & 14 & 0.7 & 1 & 1 & 1 & 9 & 0 & 0 & 1 & 1 & 0.1 & 6 & 39 & 4 & 0 & 0 \\
\hline $13 \mathrm{G}$ & 33 & 5 & 1 & 1 & 2 & 0.5 & 1 & 0.4 & 6 & 2 & 0.3 & 0 & 2 & 0.1 & 0.2 & 0 & 48 & 0 & 0 & 0 \\
\hline $14 \mathrm{G}$ & 16 & 7 & 3 & 1 & 9 & 0.5 & 0.6 & 0.5 & 0.1 & 3 & 0.4 & 0 & 0 & 2 & 0 & 0 & 58 & 0 & 0 & 0 \\
\hline $15 \mathrm{G}$ & 35 & 8 & 4 & 1 & 1 & 0.8 & 0.4 & 0.3 & 0.3 & 0.1 & 0 & 0 & 0 & 0 & 0.2 & 0 & 49 & 0 & 0 & 0 \\
\hline $16 \mathrm{G}$ & 33 & 12 & 2 & 2 & 2 & 0.5 & 1 & 0.4 & 0.4 & 2 & 1 & 0 & 0 & 1 & 0.2 & 1 & 41 & 0 & 0 & 0 \\
\hline $17 \mathrm{G}$ & 27 & 8 & 3 & 1 & 1 & 0.5 & 1 & 0 & 0.1 & 0.3 & 0 & 0 & 0 & 0 & 0.2 & 0 & 58 & 0 & 0 & 0 \\
\hline $18 \mathrm{G}$ & 12 & 2 & 1 & 0 & 34 & 0.5 & 0.3 & 0.5 & 16 & 1 & 0.3 & 0 & 0 & 0.3 & 0 & 0 & 32 & 0 & 0 & 0 \\
\hline $19 \mathrm{G}$ & 12 & 4 & 1 & 1 & 21 & 0.4 & 0.3 & 0.3 & 17 & 1 & 0.3 & 0 & 0.2 & 1 & 0 & 0 & 40 & 0 & 0 & 0 \\
\hline $20 \mathrm{G}$ & 28 & 6 & 1 & 0.3 & 1 & 0.6 & 1 & 0.4 & 0.2 & 1 & 0 & 0 & 0 & 0.1 & 0 & 0 & 62 & 0 & 0 & 0 \\
\hline $21 \mathrm{G}$ & 36 & 2 & 0.4 & 0 & 2 & 0.3 & 0.4 & 0.5 & 0.2 & 2 & 2 & 0 & 5 & 0 & 0 & 0.5 & 50 & 0 & 0 & 0 \\
\hline $22 \mathrm{G}$ & 10 & 3 & 1 & 0.3 & 28 & 0.3 & 0.5 & 1 & 19 & 2 & 1 & 0 & 0.1 & 0 & 0.1 & 0 & 34 & 0 & 0 & 0 \\
\hline $23 \mathrm{G}$ & 27 & 6 & 2 & 0 & 1 & 0.3 & 0.3 & 0.5 & 0.2 & 0.3 & 0 & 0 & 0 & 1 & 0 & 0 & 61 & 0 & 0 & 0 \\
\hline $24 \mathrm{G}$ & 21 & 8 & 2 & 1.5 & 3 & 0.5 & 0.6 & 0.3 & 1 & 0.8 & 0.1 & 0 & 0.6 & 0.1 & 0 & 0.2 & 61 & 0 & 0 & 0 \\
\hline $25 \mathrm{G}$ & 29 & 5 & 2 & 1 & 1 & 0.3 & 0.3 & 0.3 & 0.1 & 0.4 & 0.3 & 0 & 0 & 0.1 & 0 & 0 & 61 & 0 & 0 & 0 \\
\hline $26 \mathrm{G}$ & 25 & 8 & 2 & 1 & 1 & 0.4 & 0.5 & 0.4 & 0.3 & 0.4 & 0 & 0 & 0 & 0 & 0 & 0 & 61 & 0 & 0 & 0 \\
\hline $27 \mathrm{G}$ & 24 & 8 & 4 & 1 & 4 & 0.5 & 2 & 1 & 0.3 & 3 & 0.5 & 0 & 0 & 0.3 & 0.2 & 0 & 51 & 0 & 0 & 0 \\
\hline $28 \mathrm{G}$ & 25 & 6 & 1 & 1 & 0.7 & 0.4 & 0.5 & 0.3 & 0.2 & 2 & 0 & 0 & 2 & 0 & 0 & 0 & 62 & 0 & 0 & 0 \\
\hline $29 \mathrm{G}$ & 18 & 10 & 1.3 & 0.5 & 1.9 & 0.8 & 0.7 & 0.6 & 0.3 & 0.9 & 0.5 & 0 & 0.5 & 0 & 0 & 0 & 64 & 0 & 0 & 0 \\
\hline $30 \mathrm{G}$ & 6 & 1 & 8 & 0 & 0 & 0.2 & 0 & 0.9 & 0.3 & 21 & 3 & 0 & 0 & 0 & 0 & 0 & 57 & 4.4 & 0 & 0 \\
\hline $31 \mathrm{G}$ & 22 & 6 & 4 & 0.5 & 1 & 0.4 & 0.5 & 0.5 & 1 & 0.8 & 0 & 0 & 0 & 0.4 & 0 & 0 & 63 & 0 & 0 & 0 \\
\hline $32 \mathrm{G}$ & 34 & 12 & 3 & 1 & 3.5 & 1 & 0.5 & 0.3 & 2 & 0.6 & 0.1 & 0 & 0.1 & 0 & 0 & 0 & 42 & 0 & 0 & 0 \\
\hline $33 \mathrm{G}$ & 14 & 2 & 1 & 0 & 5 & 0.3 & 1 & 0.3 & 1 & 3 & 1 & 0 & 3 & 0.1 & 0 & 0 & 70 & 0 & 0 & 0 \\
\hline $34 \mathrm{G}$ & 13 & 3 & 2 & 0 & 2 & 0.4 & 1 & 1 & 1 & 13 & 1 & 0 & 3 & 0 & 0.2 & 0 & 59 & 2 & 0 & 0 \\
\hline $35 \mathrm{G}$ & 7 & 1 & 4 & 0 & 2 & 0.4 & 0.3 & 1 & 2 & 17 & 1 & 0 & 2 & 0.3 & 0 & 0 & 48 & 15 & 0 & 0 \\
\hline $36 \mathrm{G}$ & 11 & 4 & 3 & 0 & 43 & 1 & 0.2 & 0.5 & 0.6 & 2 & 0.3 & 1 & 0.2 & 1 & 0.1 & 0 & 33 & 0 & 0 & 0 \\
\hline $37 \mathrm{G}$ & 14 & 6 & 2.5 & 0.7 & 41 & 1 & 0.3 & 0 & 2.1 & 3 & 0.1 & 0 & 0.2 & 0 & 0 & 0 & 29 & 0 & 0 & 0 \\
\hline $38 \mathrm{G}$ & 25 & 8 & 1 & 0.8 & 4 & 1 & 0.9 & 0.5 & 2 & 0.6 & 0.1 & 0 & 0.5 & 0 & 0 & 0 & 55 & 0 & 0 & 0 \\
\hline $39 \mathrm{G}$ & 24 & 6.7 & 1.2 & 0.8 & 7.3 & 0.5 & 0.7 & 0.7 & 3.2 & 0.5 & 0.4 & 0 & 0.3 & 0 & 0 & 0 & 54 & 0 & 0 & 0 \\
\hline $40 \mathrm{G}$ & 23 & 9 & 1.3 & 0.7 & 5 & 0.6 & 0.4 & 0.6 & 4 & 0.6 & 0 & 0 & 0 & 0 & 0 & 0 & 55 & 0 & 0 & 0 \\
\hline
\end{tabular}

\section{Discussion}

\section{Evaluation of the ceramic bodies}

The binary diagram $\mathrm{SiO}_{2}-\mathrm{Al}_{2} \mathrm{O}_{3}$ of ceramic bodies, using the XRF data listed in Table 2 grouped by dating (Fig. 12), shows that the first group of the earliest vessels (red) has the smallest differences in composition.
The majority of the ceramic materials from the group of the earliest vessels were tempered using bimodal temper with large inclusions of quartz and feldspars. The ceramic bodies of these vessels probably contain a higher amount of a non-plastic component than most of the ceramic bodies from the other two groups. 
Table 5 Chemical composition of the glazes of all studied finds analysed after the chemical cleaning of corrosion layers (wt\%)

\begin{tabular}{|c|c|c|c|c|c|c|c|c|c|c|c|c|c|c|c|c|c|c|c|c|}
\hline mple & $\mathrm{SiO}_{2}$ & $\mathrm{Al}_{2} \mathrm{O}_{3}$ & $\mathrm{Fe}_{2} \mathrm{O}_{3}$ & $\mathrm{TiO}_{2}$ & $\mathrm{CaO}$ & $\mathrm{MgO}$ & $\mathrm{K}_{2} \mathrm{O}$ & $\mathrm{Na}_{2} \mathrm{O}$ & $\mathrm{P}_{2} \mathrm{O}_{5}$ & $\mathrm{SO}_{3}$ & $\mathrm{Cl}$ & $\mathrm{MnO}$ & $\mathrm{CuO}$ & $\mathrm{ZnO}$ & $\mathrm{ZrO}_{2}$ & $\mathrm{BaO}$ & $\mathrm{PbO}$ & $\mathrm{SnO}_{2}$ & $\mathrm{~b}_{2} \mathrm{O}_{3}$ & $\mathrm{Bi}_{2} \mathrm{O}_{3}$ \\
\hline $1 \mathrm{G}$ & 23.6 & 3.6 & 7.2 & 0.3 & 2.1 & 0.2 & 0.3 & 0.2 & 1.7 & 1.0 & 0.0 & 0.0 & 0.1 & 2.1 & 0.0 & 0.0 & 57.4 & 0.0 & 0.2 & 0.0 \\
\hline $2 G$ & 48.8 & 6.0 & 0.9 & 0.4 & 1.8 & 0.2 & 1.0 & 0.3 & 1.6 & 0.8 & 0.2 & 0.0 & 2.0 & 0.0 & 0.0 & 0.1 & 35.6 & 0.0 & 0.2 & 0.0 \\
\hline $3 G$ & 34.0 & 1.2 & 0.5 & 0.1 & 2.0 & 0.2 & 0.3 & 0.1 & 0.1 & 0.9 & 2.1 & 0.0 & 5.6 & 0.0 & 0.0 & 0.0 & 52.6 & 0.0 & 0.2 & 0.1 \\
\hline $4 G$ & 31.4 & 2.7 & 5.1 & 0.3 & 3.0 & 0.4 & 0.8 & 0.4 & 6.1 & 0.3 & 0.0 & 0.0 & 0.1 & 0.2 & 0.0 & 0.4 & 48.6 & 0.0 & .2 & 0.0 \\
\hline $5 G$ & 33.0 & 3.1 & 4.0 & 0.3 & 0.3 & 0.3 & 0.5 & 0.2 & 0.1 & 0.1 & 0.2 & 0.0 & 0.1 & 0.8 & 0.0 & 0.0 & 57.0 & 0.0 & 0.1 & 0.0 \\
\hline $6 G$ & 34.4 & 1.0 & 6.3 & 0.0 & 1.0 & 0.1 & 0.6 & 0.5 & 1.7 & 1.3 & 0.5 & 0.0 & 0.1 & 5.3 & 0.0 & 0.0 & 46.9 & 0.0 & 0.1 & 0.0 \\
\hline $7 G$ & 47.3 & 4.8 & 0.7 & 0.4 & 1.4 & 0.3 & 1.0 & 0.5 & 1.1 & 0.8 & 0.6 & 0.0 & 3.6 & 0.0 & 0.0 & 0.0 & 37.0 & 0.0 & 0.2 & 0.1 \\
\hline $8 \mathrm{G}$ & 29.0 & 3.3 & 4.0 & 0.3 & 0.2 & 0.2 & 0.3 & 0.3 & 0.1 & 0.1 & 0.1 & 0.0 & 0.1 & 0.8 & 0.0 & 0.0 & 61.0 & 0.0 & 0.3 & 0.0 \\
\hline $9 \mathrm{G}$ & 29.2 & 2.1 & 6.0 & 0.3 & 0.7 & 0.3 & 0.2 & 0.2 & 0.6 & 0.1 & 0.2 & 0.0 & 0.1 & 0.1 & 0.0 & 0.0 & 59.4 & 0.0 & 0.4 & 0.0 \\
\hline$D G$ & 31.3 & 4.0 & 0.8 & 0.3 & 0.6 & 0.4 & 0.4 & 0.2 & 0.1 & 0.1 & 0.0 & 0.0 & 2.0 & 0.0 & 0.0 & 0.0 & 59.5 & 0.0 & .0 & 0.2 \\
\hline $11 \mathrm{G}$ & 29.5 & 3.1 & 5.1 & 0.4 & 2.0 & 0.3 & 0.2 & 0.1 & 0.9 & 0.2 & 0.0 & 0.0 & 0.1 & 0.1 & 0.0 & 0.0 & 58.0 & 0.0 & 0.0 & 0.0 \\
\hline $12 \mathrm{G}$ & 32.4 & 2.7 & 1.0 & 0.2 & 0.5 & 0.2 & 0.3 & 0.2 & 0.2 & 0.0 & 0.1 & 0.0 & 2.0 & 0.0 & 0.0 & 0.0 & 42.5 & 17.2 & 0.3 & 0.0 \\
\hline $13 \mathrm{G}$ & 30.3 & 5.0 & 0.6 & 0.2 & 0.7 & 0.3 & 0.5 & 0.4 & 0.2 & 0.2 & 0.0 & 0.0 & 4.0 & 0.0 & 0.0 & 0.0 & 57.5 & 0.0 & 0.0 & 0.0 \\
\hline $14 \mathrm{G}$ & 28.2 & 6.0 & 2.0 & 0.6 & 0.9 & 0.4 & 0.4 & 0.2 & 0.1 & 0.5 & 0.1 & 0.0 & 0.0 & 1.0 & 0.1 & 0.0 & 59.4 & 0.0 & 0.0 & 0.0 \\
\hline $15 \mathrm{G}$ & 35.7 & 7.0 & 4.0 & 0.6 & 0.6 & 0.6 & 0.3 & 0.1 & 0.1 & 0.0 & 0.1 & 0.0 & 0.2 & 0.0 & 0.1 & 0.0 & 50.6 & 0.0 & 0.0 & 0.0 \\
\hline $16 \mathrm{G}$ & 29.0 & 6.0 & 2.0 & 0.7 & 0.2 & 0.2 & 0.4 & 0.2 & 0.3 & 0.2 & 0.2 & 0.0 & 0.0 & 1.3 & 0.0 & 0.0 & 59.1 & 0.0 & 0.1 & 0.0 \\
\hline $17 \mathrm{G}$ & 29.0 & 7.0 & 3.0 & 1.0 & 2.0 & 0.5 & 0.7 & 0.2 & 0.2 & 0.1 & 0.2 & 0.1 & 0.1 & 0.0 & 0.0 & 0.0 & 55.9 & 0.0 & 0.0 & 0.0 \\
\hline $18 \mathrm{G}$ & 41.4 & 0.9 & 0.3 & 0.0 & 0.6 & 0.2 & 0.3 & 0.1 & 0.2 & 0.2 & 0.9 & 0.0 & 0.1 & 0.2 & 0.0 & 0.0 & 54.6 & 0.0 & 0.0 & 0.0 \\
\hline $19 \mathrm{G}$ & 26.0 & 6.0 & 2.0 & 0.5 & 4.0 & 0.5 & 0.6 & 0.3 & 1.7 & 0.1 & 0.2 & 0.0 & 0.1 & 0.1 & 0.0 & 0.0 & 58.0 & 0.0 & 0.0 & 0.0 \\
\hline $20 \mathrm{G}$ & 30.3 & 6.1 & 1.0 & 0.5 & 2.0 & 0.5 & 0.8 & 0.2 & 0.1 & 0.5 & 0.2 & 0.2 & 0.0 & 0.0 & 0.0 & 0.0 & 57.6 & 0.0 & 0.0 & 0.0 \\
\hline $21 \mathrm{G}$ & 51.5 & 2.0 & 0.3 & 0.2 & 0.7 & 0.2 & 0.5 & 0.2 & 0.4 & 0.4 & 2.2 & 0.0 & 4.0 & 0.0 & 0.0 & 0.0 & 37.3 & 0.0 & 0.0 & 0.0 \\
\hline $22 \mathrm{G}$ & 29.1 & 8.0 & 2.0 & 0.4 & 0.5 & 0.5 & 1.1 & 0.5 & 0.1 & 0.3 & 0.3 & 0.0 & 0.1 & 0.0 & 0.0 & 0.0 & 57.1 & 0.0 & 0.0 & 0.0 \\
\hline $23 \mathrm{G}$ & 29.4 & 6.1 & 2.0 & 0.8 & 0.7 & 0.4 & 0.3 & 0.2 & 0.1 & 0.1 & 0.0 & 0.1 & 0.1 & 0.6 & 0.0 & 0.0 & 58.8 & 0.0 & 0.3 & 0.0 \\
\hline $24 \mathrm{G}$ & 24.9 & 9.0 & 1.6 & 1.5 & 1.7 & 0.3 & 0.6 & 0.3 & 0.2 & 0.1 & 0.0 & 0.0 & 0.6 & 0.1 & 0.0 & 0.2 & 58.8 & 0.0 & 0.1 & 0.0 \\
\hline $25 \mathrm{G}$ & 32.9 & 6.0 & 3.0 & 0.7 & 0.6 & 0.2 & 0.4 & 0.1 & 0.1 & 0.1 & 0.2 & 0.0 & 0.0 & 0.0 & 0.0 & 0.0 & 55.8 & 0.0 & 0.0 & 0.0 \\
\hline $26 \mathrm{G}$ & 23.2 & 7.1 & 3.0 & 0.5 & 0.8 & 0.4 & 0.3 & 0.1 & 0.1 & 0.7 & 0.1 & 0.0 & 0.0 & 0.0 & 0.0 & 0.0 & 63.6 & 0.0 & 0.0 & 0.0 \\
\hline $27 \mathrm{G}$ & 40.3 & 9.1 & 4.0 & 0.8 & 0.3 & 0.6 & 0.6 & 0.2 & 0.2 & 0.2 & 0.0 & 0.0 & 0.0 & 0.3 & 0.0 & 0.0 & 43.3 & 0.0 & 0.0 & 0.0 \\
\hline $28 \mathrm{G}$ & 29.8 & 6.1 & 1.0 & 1.0 & 0.7 & 0.4 & 0.6 & 0.3 & 0.2 & 0.3 & 0.0 & 0.0 & 1.9 & 0.0 & 0.1 & 0.0 & 57.4 & 0.0 & 0.0 & 0.0 \\
\hline $29 \mathrm{G}$ & 25.0 & 11.0 & 1.3 & 0.4 & 0.8 & 0.4 & 0.6 & 0.5 & 0.1 & 0.2 & 0.1 & 0.0 & 0.4 & 0.0 & 0.0 & 0.0 & 59.1 & 0.0 & 0.1 & 0.0 \\
\hline $30 \mathrm{G}$ & 10.3 & 0.8 & 2.8 & 0.4 & 0.1 & 0.3 & 0.4 & 0.2 & 0.1 & 21.0 & 0.0 & 0.4 & 0.4 & 0.0 & 0.0 & 0.0 & 58.6 & 4.4 & 0.0 & 0.0 \\
\hline $31 \mathrm{G}$ & 22.8 & 5.4 & 2.2 & 0.5 & 0.2 & 0.1 & 0.3 & 0.2 & 0.2 & 0.9 & 0.0 & 0.0 & 0.0 & 0.5 & 0.1 & 0.0 & 66.4 & 0.0 & 0.0 & 0.0 \\
\hline $32 \mathrm{G}$ & 42.1 & 13.0 & 2.5 & 1.0 & 0.8 & 0.5 & 0.3 & 0.2 & 0.2 & 0.0 & 0.0 & 0.0 & 0.1 & 0.0 & 0.0 & 0.0 & 39.1 & 0.0 & 0.0 & 0.0 \\
\hline $33 \mathrm{G}$ & 28.4 & 2.2 & 0.5 & 0.2 & 0.7 & 0.2 & 0.2 & 0.1 & 0.1 & 0.3 & 0.0 & 0.0 & 0.1 & 3.0 & 0.0 & 0.0 & 63.9 & 0.0 & 0.0 & 0.0 \\
\hline $34 \mathrm{G}$ & 15.0 & 2.3 & 2.0 & 0.0 & 0.3 & 0.2 & 0.5 & 0.2 & 0.1 & 18.0 & 0.2 & 0.1 & 3.0 & 0.0 & 0.0 & 0.0 & 55.0 & 3.0 & 0.0 & 0.0 \\
\hline $35 \mathrm{G}$ & 5.1 & 0.9 & 4.1 & 0.0 & 0.2 & 0.3 & 0.1 & 0.1 & 0.1 & 22.7 & 0.2 & 0.0 & 3.0 & 0.3 & 0.0 & 0.0 & 43.6 & 19.3 & 0.0 & 0.0 \\
\hline $36 \mathrm{G}$ & 26.9 & 6.0 & 4.0 & 0.3 & 0.8 & 0.5 & 0.5 & 0.9 & 0.4 & 0.0 & 0.1 & 2.0 & 0.1 & 1.0 & 0.0 & 0.5 & 55.8 & 0.0 & 0.2 & 0.0 \\
\hline $37 \mathrm{G}$ & 28.9 & 8.0 & 3.5 & 1.7 & 0.8 & 0.5 & 0.6 & 0.2 & 1.1 & 0.1 & 0.1 & 0.0 & 0.4 & 0.0 & 0.1 & 0.0 & 53.8 & 0.0 & 0.3 & 0.0 \\
\hline $38 \mathrm{G}$ & 32.7 & 10.0 & 1.0 & 1.0 & 0.6 & 0.3 & 0.3 & 0.1 & 0.1 & 0.1 & 0.0 & 0.0 & 0.5 & 0.0 & 0.0 & 0.0 & 53.2 & 0.0 & 0.0 & 0.0 \\
\hline $39 \mathrm{G}$ & 32.9 & 9.9 & 1.4 & 1.4 & 1.7 & 0.4 & 0.3 & 0.2 & 0.5 & 0.1 & 0.0 & 0.0 & 0.3 & 0.0 & 0.1 & 0.0 & 50.8 & 0.0 & 0.0 & 0.0 \\
\hline $40 \mathrm{G}$ & 31.2 & 10.1 & 1.3 & 0.7 & 1.4 & 0.2 & 0.2 & 0.5 & 1.5 & 0.1 & 0.0 & 0.0 & 0.1 & 0.0 & 0.0 & 0.0 & 52.4 & 0.0 & 0.3 & 0.0 \\
\hline
\end{tabular}

Similar amounts of plastic and non-plastic components were proved to be present in the ceramic bodies of the vessels from the second and third groups. The presence of minority components $\left(\mathrm{Fe}_{2} \mathrm{O}_{3}, \mathrm{~K}_{2} \mathrm{O}\right.$, $\mathrm{Na}_{2} \mathrm{O}, \mathrm{CaO}$ and $\mathrm{MgO}-$ Fig. 3) reflects the division into groups. Differences that occurred over time were probably caused by the variability of raw materials in nearby territories.

The mineralogical compositions determined using $\mathrm{XRD}$ analysis proved that the main crystalline phase in all 

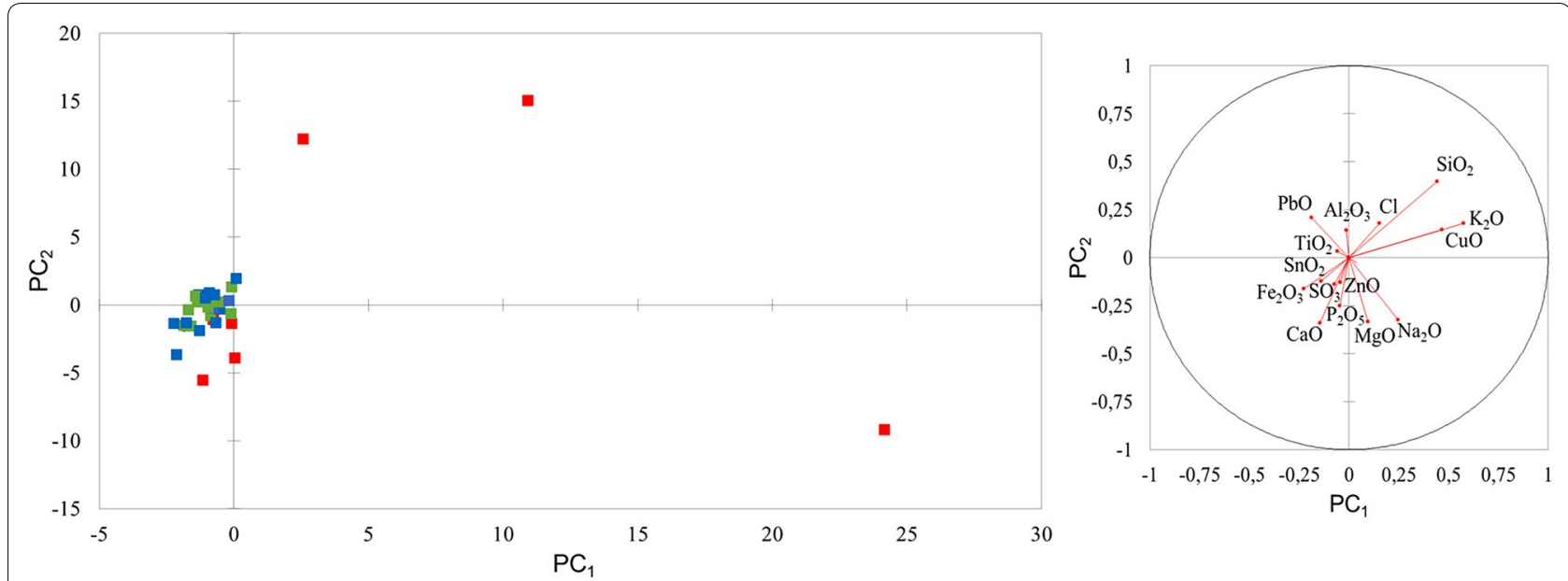

Fig. 5 PCA biplot of corrosion products on the surfaces of the glazes. On the left hand side-observation plot in which XRF data of individual samples of glazes are related to one another. On the right hand side-correlation circle with vectors of investigated variables
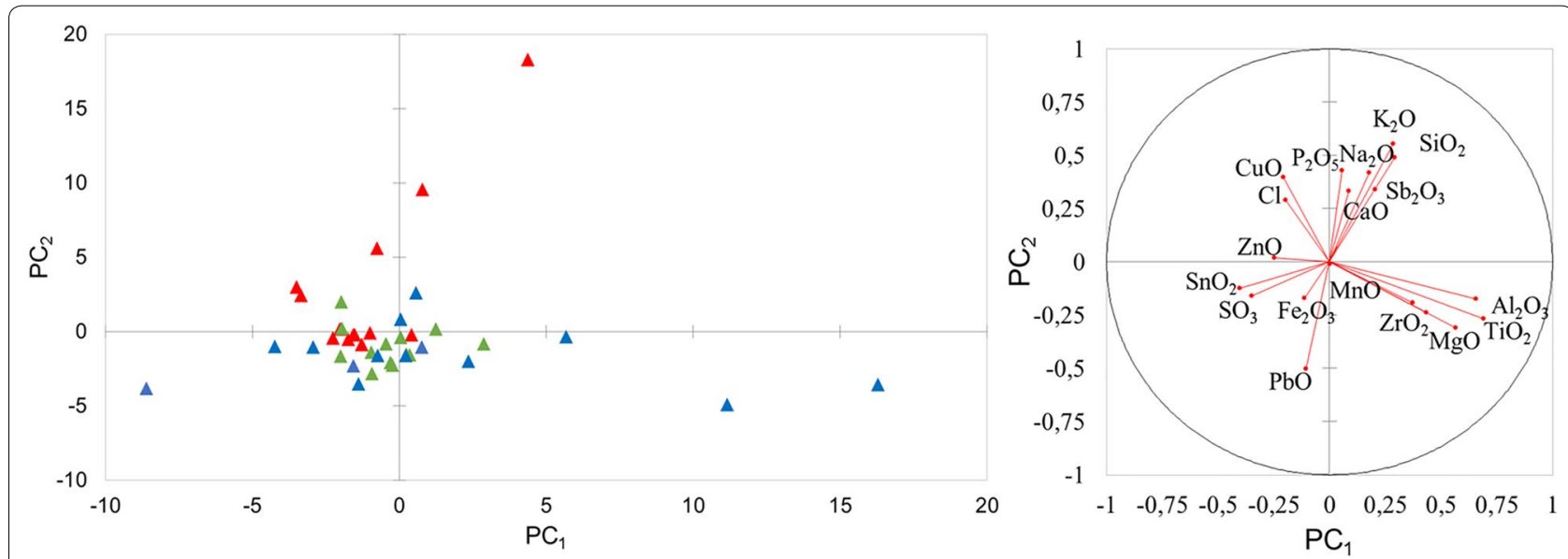

Fig. 6 PCA biplot of glazes after cleaning using a 5\% acid solution. On the left hand side-observation plot in which XRF data of individual samples of glazes are related to one another. On the right hand side-correlation circle with vectors of investigated variables
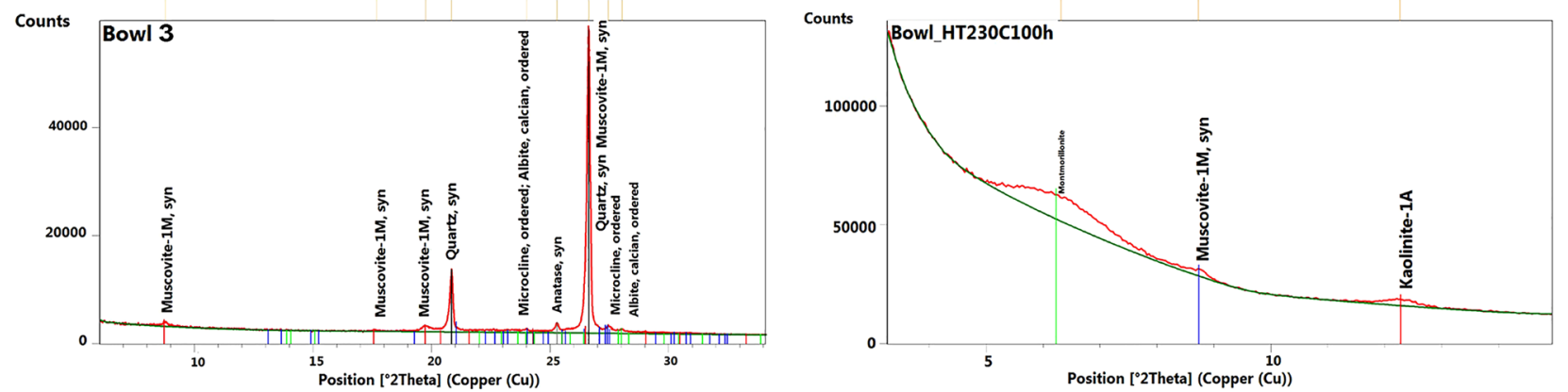

Fig. 7 XRD pattern of the ceramic body of the bowl before hydrothermal loading (left hand side) and a detail of the XRD pattern of the same sample after hydrothermal loading (right hand side) 
Table 6 Main normative mineral compositions calculated from the chemical compositions of the ceramic bodies

\begin{tabular}{|c|c|c|c|c|c|c|c|c|c|c|c|c|c|c|c|c|}
\hline \multirow[t]{2}{*}{ Sample } & \multicolumn{12}{|c|}{ Content (wt\%) } & \multicolumn{4}{|c|}{ Parameters of ceramic bodies } \\
\hline & Fsp & Q & $\mathrm{Mm}$ & III & $\mathrm{Chl}$ & $\mathrm{Kn}$ & Ap & Ank & $\mathrm{Ht}$ & Rt & $\mathrm{HI}$ & Gy & $\mathrm{OH}\left(\mathrm{g} \mathrm{cm}^{-3}\right)$ & $E(\%)$ & $P_{a p}(\%)$ & $d_{a p}\left(g ~ c m^{-3}\right)$ \\
\hline Lid 2 & 0 & 32.36 & 6.35 & 15.99 & 1.96 & 38.63 & 1.55 & 0 & 1.83 & 1.12 & 0.02 & 0.20 & 1.824 & 16.65 & 30.34 & 2.62 \\
\hline Bowl 3 & 0 & 32.31 & 4.14 & 13.94 & 2.06 & 41.41 & 2.87 & 0 & 1.15 & 1.21 & 0.31 & 0.60 & 1.837 & 16.57 & 30.30 & 2.64 \\
\hline $\operatorname{Jar} 7$ & 0 & 37.47 & 6.71 & 17.17 & 1.90 & 33.40 & 0.90 & 0.12 & 0.89 & 1.04 & 0 & 0.41 & 1.823 & 16.62 & 30.44 & 2.63 \\
\hline
\end{tabular}

Fsp feldspars, Q quartz, Mm montmorillonite, III illite, ChI chlorite, Kn kaolinite, Ap apatite, Ank ankerite, $H$ t hematite, Rt rutile, HI halite, Gy gypsum, bulk density OH; water absorption $\mathrm{E}$; apparent porosity $\mathrm{P}_{\mathrm{ap}}$; apparent density $\mathrm{d}_{\mathrm{ap}}$
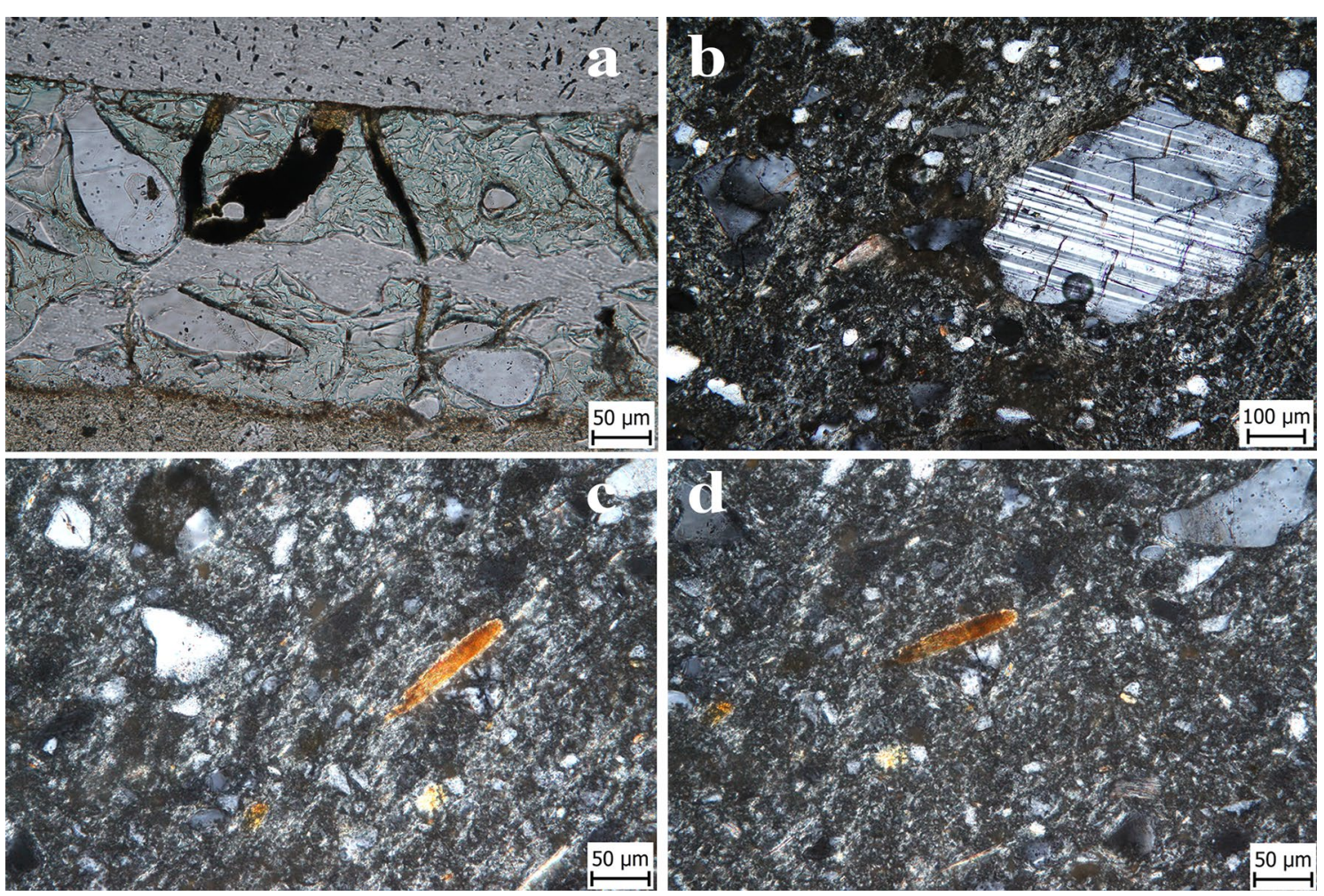

Fig. 8 OM images of the thin sections of bowl no. 3: a glaze; b feldspar plagioclase; c, $\mathbf{d}$ very slightly optically active matrix with lamellar mica grains; a without crossed polarizers; $\mathbf{b}-\mathbf{d}$ with crossed polarizers

samples was quartz accompanied by feldspars and mica. Some samples contained anatase, hematite and mullite. The presence of a high-temperature phase mullite shows that the firing temperature of some vessels reached, or slightly exceeded, $1000{ }^{\circ} \mathrm{C}$. Such vessels fired at a higher temperature were identified in all of the studied chronological groups (Fig. 13).

\section{Evaluation of the glazes and their degradation}

A chemical analysis of the glazes proved that the studied samples were medium- or high-lead content glazes with a $\mathrm{PbO}$ content of $35-67 \mathrm{wt} \%$. The lowest $\mathrm{PbO}$ content was identified in the samples taken from the distillation lid (no. 2) and the flowerpot (no. 21). Their lower lead content is caused by the leaching of $\mathrm{Pb}$ during their use. Corrosion products, especially in a form of lead compounds, were identified on the surfaces of the samples. Figure 14 shows the colours of the ceramic bodies and the glazes, including colouring agents (determined using the XRF results listed in Table 5), corrosion products (determined using XRD) and identified defects.

The majority of the glazes (77\%) did not contain any crystalline phase (according to XRD). The other glazes contained mainly quartz. Cassiterite-one of the oldest known opacifiers-was identified (by XRD) in the glaze of four vessels with black glazes (pot no. 12, pipkins nos. 30 and 35 and small bowl no. 34) [62]. The presence of kaolinite and gypsum on the glaze surfaces was caused 


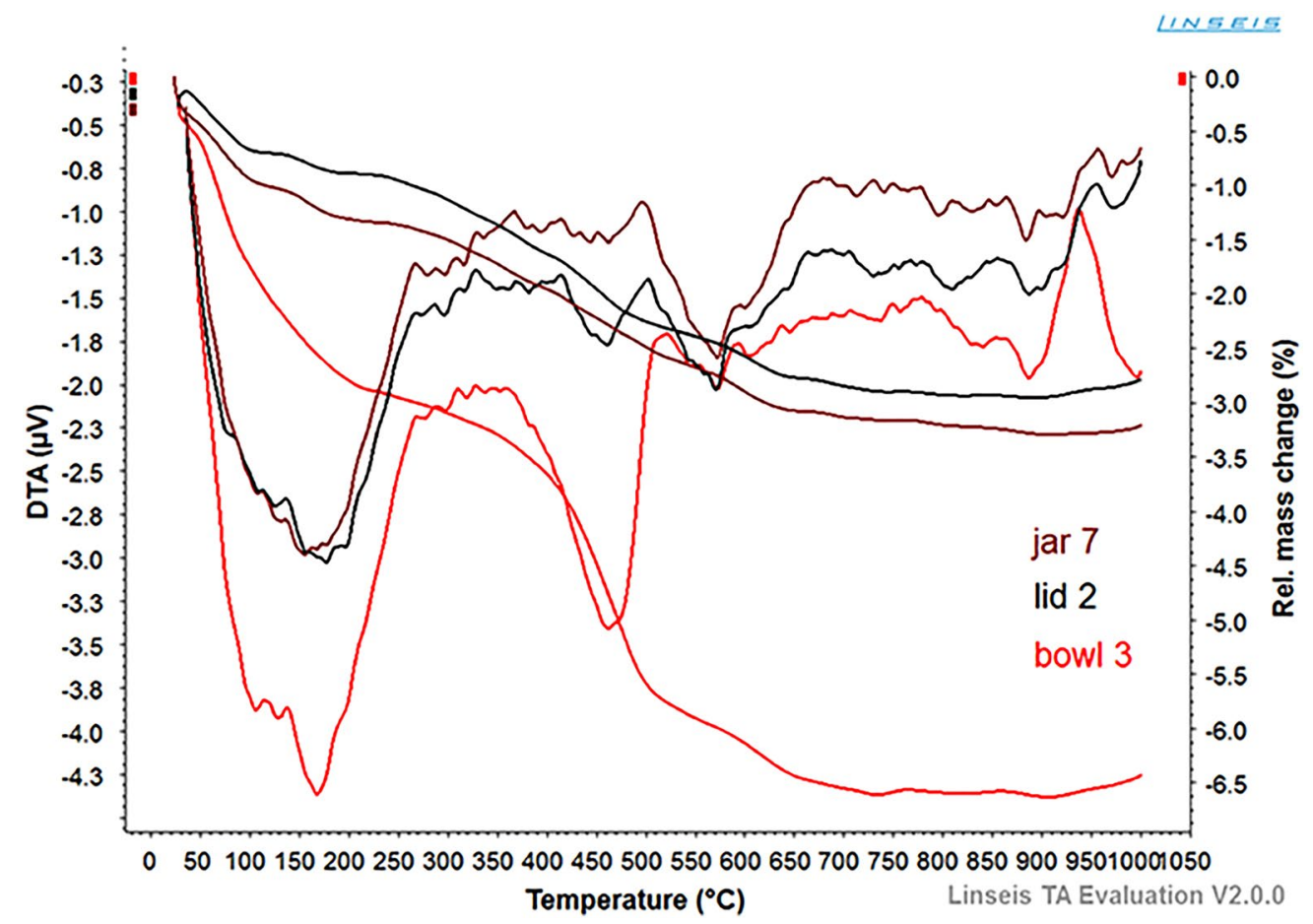

Fig. 9 DTA-TG curves of hydrothermally treated samples of the ceramic bodies of the technical ceramic vessels

by secondary contamination from restoration work, or from the surrounding environment. Sulphides or sulphates were identified in the green glazes of bowl no. 3, the black glazes used on pipkins nos. 30 and 35, and the black-green glaze of small bowl no. 34 . The presence of sulphides in the glazes caused their very dark colouring. A probable cause of $\mathrm{PbS}$ presence in glazes is biodegradation in waste pit environments. Glazes, with the exception of the three dark glazes mentioned above and the transparent glaze (no. 18), were coloured by a combination of ionic colourants, particularly metal ions such as $\mathrm{Fe}, \mathrm{Cu}, \mathrm{Sb}, \mathrm{Mn}$. The majority of the glazes are coloured in various earthy tones such as yellow-ochre, ochre, orangebrown or brown. $\mathrm{Cu}$ is known to give a green colour to lead glazes and, for the green colours of this set of vessels, a $\mathrm{CuO}$ content of $2-5.5$ wt \% (sample nos. 2, 3, 7, $10,12,13,21,34$ and 35 ) is essential. Fe (in the range of 0.5-7 wt\%) was also present in all $\mathrm{Cu}$-containing glazes (in total, 33 glazes containing $0.1-5.5 \mathrm{wt} \% \mathrm{CuO}$ ). This component can enter the glaze either as a component of the raw materials used for the glaze or by the dissolution of $\mathrm{Fe}$ compounds from a ceramic body during firing. The first case comprises glazes with more than twice the amount of Fe content when compared to the Fe content in the ceramic body, e.g. $2.3 \% \mathrm{Fe}_{2} \mathrm{O}_{3}$ in light coloured shard no. 1 covered with a brown glaze with $7 \% \mathrm{Fe}_{2} \mathrm{O}_{3}$. It was found that if the $\mathrm{Cu}$ component (above 2\%) is more than twice that of $\mathrm{Fe}$, the green colour is intense. At a lower $\mathrm{Cu} / \mathrm{Fe}$ ratio or a lower $\mathrm{CuO}$ content (below $2 \%$ in the presence of a $\mathrm{Fe}$ component with a content above $1 \%)$, the colour is mixed greenish-brown as in the case of sample no. 28. In such glazes, the above mentioned effect of dissolving the Fe component from the ceramic body during firing could also contribute to the colour. On the other hand, in the case of semi-transparent and transparent glazes, the colour of the ceramic body plays an important role, as in the case of the semi-transparent glaze of sample no. 13 with $4 \% \mathrm{CuO}$ and $0.6 \% \mathrm{FeO}$ in the glaze and $5 \% \mathrm{FeO}$ in the ceramic body, or of the transparent glaze of sample no. 18 with $0.3 \% \mathrm{FeO}$ content in the glaze and $4 \% \mathrm{FeO}$ content in the ceramic body. The brown, orange, light brown and yellow tones of glazes are caused by the presence of Fe components. In yellow glazes, the $\mathrm{Pb}-\mathrm{Sb}$ component (sample nos. 8, 9, 16, 23 and 24) is more involved. Ti, $\mathrm{Zn}, \mathrm{Ca}$ are not explicitly dye components, but act as nucleating agents in the opacification or toning of glazes and can thus influence the final colour of a glaze. The surface of the glazes was free of pinholes and other signs of defects indicating a single firing process. Therefore, it may be expected that the glazes were applied on biscuit fired ceramic bodies. 
Table 7 Chemical composition of the glazes of samples before (B) and after (A) the surfaces were cleaned, converted to molar percentage; main components

\begin{tabular}{|c|c|c|c|c|c|c|c|c|c|c|c|c|c|}
\hline \multirow[t]{2}{*}{ Samples } & \multicolumn{12}{|c|}{ Content (mol\%) } & \multirow{2}{*}{$\begin{array}{l}\text { Colour } \\
\text { L*a*b* }^{*}\end{array}$} \\
\hline & $\mathrm{SiO}_{2}$ & $\mathrm{Al}_{2} \mathrm{O}_{3}$ & $\mathrm{PbO}$ & $\mathrm{Fe}_{2} \mathrm{O}_{3}$ & $\mathrm{CaO}$ & $\mathrm{TiO}_{2}$ & $\mathrm{~K}_{2} \mathrm{O}$ & $\mathrm{Na}_{2} \mathrm{O}$ & $\mathrm{MgO}$ & $\mathrm{CuO}$ & $\mathrm{P}_{2} \mathrm{O}_{5}$ & $\mathrm{Sb}_{2} \mathrm{O}_{3}$ & \\
\hline 2 lid-glaze A & 72.05 & 5.22 & 14.14 & 0.51 & 2.89 & 0.45 & 0.96 & 0.44 & 0.45 & 2.27 & 0.51 & 0.12 & $44^{*}-4^{*} 16^{*}$ \\
\hline 2 lid-glaze B & 64.98 & 6.29 & 14.16 & 0.64 & 5.80 & 0.58 & 1.97 & 0.90 & 0.69 & 2.57 & 1.28 & 0.12 & $45^{*}-2^{*} 14^{*}$ \\
\hline 3 bowl-glaze $A$ & 60.58 & 1.30 & 25.20 & 0.35 & 3.74 & 0.14 & 0.35 & 0.12 & 0.55 & 7.49 & 0.04 & 0.15 & $38^{*}-5^{*} 4^{*}$ \\
\hline 3 bowl-glaze B & 59.40 & 2.80 & 27.72 & 0.82 & 2.97 & 0.45 & 0.63 & 0.38 & 0.89 & 3.74 & 0.13 & 0.08 & $36^{*}-5^{*} 5^{*}$ \\
\hline 7 jar-glaze A & 70.71 & 2.59 & 14.90 & 0.19 & 1.27 & 0.23 & 0.88 & 0.93 & 0.69 & 4.49 & 0.36 & 0.12 & $38^{*}-9^{*} 11^{*}$ \\
\hline 7 jar-glaze B & 61.79 & 4.60 & 17.07 & 0.55 & 4.70 & 0.37 & 1.76 & 1.58 & 1.94 & 4.78 & 0.85 & 0.13 & $42^{*}-3^{*} 12^{*}$ \\
\hline
\end{tabular}

\section{Distillation apparatus}

Special attention was paid to the analyses of the technical ceramic vessels (rectification lid no. 2, jar no. 7 and bowl no. 3). The aim was to prove that these vessels were products of the same workshop and could have originally formed one distillation apparatus. The chemical composition of the three vessels is very similar (Fig. 4, black circle, and Table 4, in green). As far as the composition of the ceramic bodies is concerned, only small differences occur in the proportion of $\mathrm{CaO}, \mathrm{MgO}$, and $\mathrm{K}_{2} \mathrm{O}$ contents, demonstrating an overall homogeneity of the raw material. The results of the evaluation of thin sections (Fig. 6) are consistent with XRD (Table 4) and XRF (Tables 2, 3) results. All three vessels exhibit a similar microstructure, matrix and size, as well as a similar type of non-plastic material (particularly silica grains). Occasionally, mica (muscovite), $\mathrm{K}-$ feldspars and $\mathrm{Fe}-$ pigmentation were also observed. The greatest differences between the XRD results and the calculated mineralogical composition are in the content of individual clay minerals (Table 6). Clay minerals convert to amorphous meta-clays at temperatures between 500 and $1000{ }^{\circ} \mathrm{C}$ and so they cannot be detected by XRD. At temperatures above $900{ }^{\circ} \mathrm{C}$, they convert to defective spinel and then to mullite. Traces of mullite were identified only in the jar sample. A very slightly "optically active" matrix with lamellar mica grains was observed in the bowl sample.

We may assume that the vessels were fired at temperatures between 850 and $980{ }^{\circ} \mathrm{C}$ as evidenced by the very slightly "optically active" matrix and the absence of rutile (anatase transforms into rutile at temperatures over $920^{\circ} \mathrm{C}$ ). Similarities in ceramic body parameters (Table 6 , right hand side) of all three vessels indicate that the vessels were fired within approximately the same temperature range. The results of the thermal analyses are consistent with the vessels' mineralogical composition determined by XRD and optical microscopy. The largest amount of water was released from bowl no. 3 (Fig. 7a, red line). We may assume that this is related to the higher content of kaolinite clay (the characteristic dehydration/ dehydroxylation and formation of spinel when kaolinitic clay is fired, Fig. 7a, red line) and the highest temperature load (approx. $100{ }^{\circ} \mathrm{C}$ ) during its usage in comparison to the other two vessels [63]. The lowest degree of rehydroxylation was observed in the jar (Fig. 7a, brown line). In this case, this is probably due to the intensive thermal load during firing, as XRD proved traces of mullite in its ceramic body. DTA results (characteristic dehydration/ dehydroxylation and the formation of spinel during the clay calcination, see Fig. 7a, brown line) confirmed this assumption.

The green glazes, present on all of the examined vessels, are uneven with thicknesses ranging between 40 and $200 \mu \mathrm{m}$ (Figs. 8a, 10a, b) and show significant signs of degradation that was probably caused not only by their preservation in a waste pit but also by their usage. The corrosion products on the green glazes were identified by XRD as lead and calcium phosphates, both usually originating in waste pits from kitchen waste, such as bones. The occurrence of kaolinite and gypsum on the glaze surfaces was caused by secondary contamination from the previous restoration work, or from the surrounding environment. We assume that in a composition range of up to ca $30 \mathrm{~mol} \%$, lead cations tend to act as network modifiers. Lead ions behave similarly as alkali metal cations and form an ionic bond with non-bridging oxygens at up to about $30 \mathrm{~mol} \%$ of $\mathrm{PbO}$. The chemical characteristics of the $\mathrm{Pb}-\mathrm{O}$ bond change from an ionic character to be more covalent when the $\mathrm{PbO}$ content increases above $30 \mathrm{~mol} \%$ to better suit the needs of the glass formation of an oxide glass network. When the $\mathrm{PbO}$ content is increased to over $60 \mathrm{~mol} \%$, lead forms its own glassy structure, due to the properties of lead ions to produce a glassy network over a wide range of concentrations of up to more than $80 \mathrm{~mol} \% \mathrm{PbO}$, if the melt is cooled rapidly [64-66]. $\mathrm{Pb}$ ions leached from the glazed surfaces are therefore involved in the formation of the corrosion products detected by SEM. X-ray fluorescence analysis of 

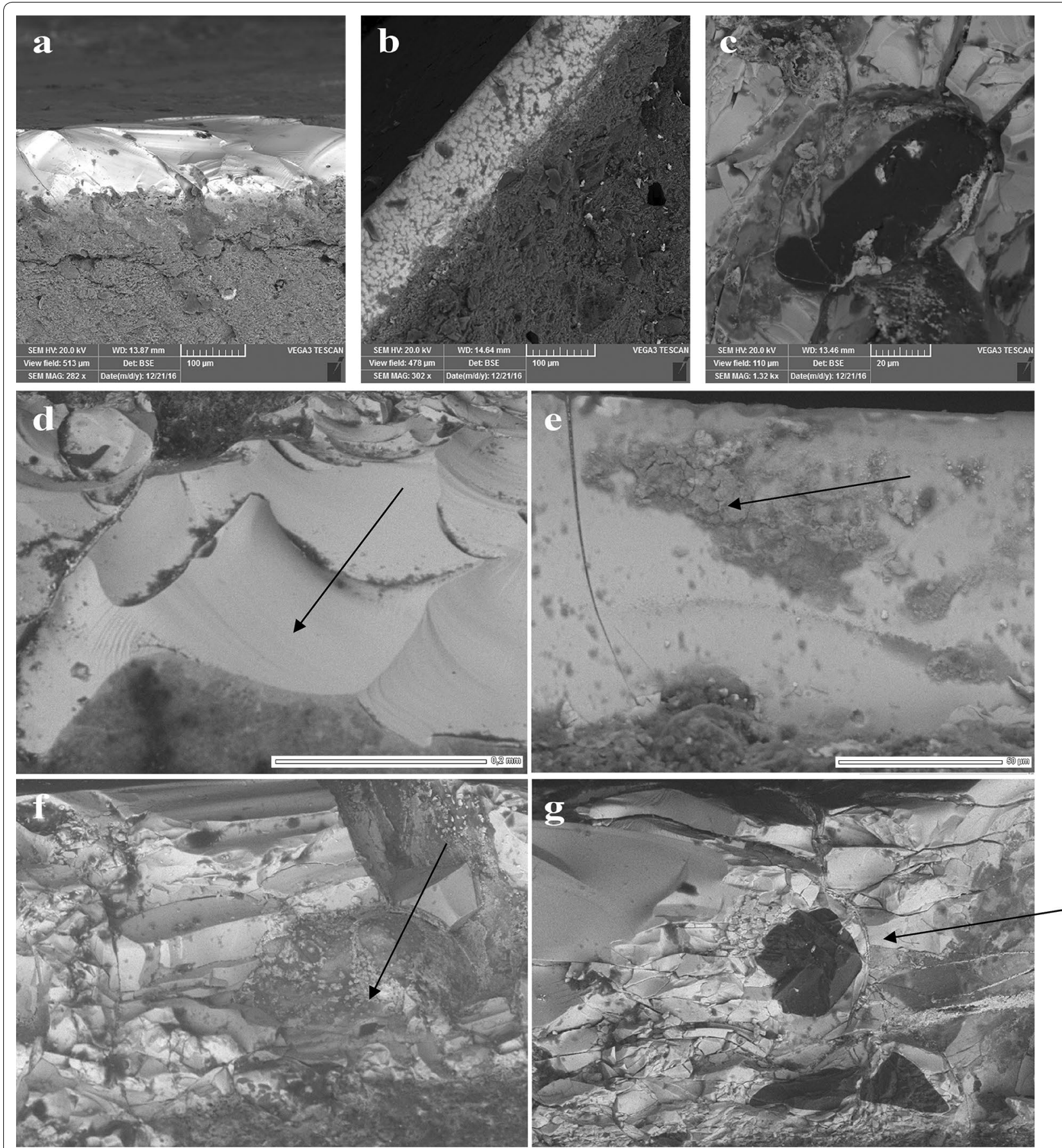

Fig. 10 SEM images of the glazes on the vessel samples: $\mathbf{b}$ fragment of lid no. 2, c fragment of bowl no. 3; $\mathbf{a}, \mathbf{d}-\mathbf{g}$ fragments of jar no. 7. Arrows show the points of spot analysis, which are listed in Table 8

the cleaned glazes confirmed that the surface of the glazes was covered by corrosion products containing lead. Other observed defects were of a different type. Large grains of quartz in the raw material caused cracking in the glaze resulting from volume changes accompanying the transformation of $\alpha \rightarrow \beta$ quartz during the process of cooling after a vessel was fired. The varying $\mathrm{PbO}$ content indicates the degree of corrosion in the lead component, depending on how long the vessel was used and exposed to the corrosive environment: vapour from distilled solutions in the case of the lids, boiling liquid in the case of the bowl and hot distillate in the case of the jar. 
Table 8 Chemical composition of the glaze and corrosion products of jar no. 7 as determined by EDS analysis

\begin{tabular}{|c|c|c|c|c|c|c|c|c|c|c|}
\hline & \multicolumn{10}{|c|}{ Content (wt\%) } \\
\hline & $\mathrm{Al}_{2} \mathrm{O}_{3}$ & $\mathrm{SiO}_{2}$ & $\mathrm{CaO}$ & $\mathrm{Fe}_{2} \mathrm{O}_{3}$ & $\mathrm{CuO}$ & $\mathrm{PbO}$ & $\mathrm{P}_{2} \mathrm{O}_{5}$ & $\mathrm{SO}_{3}$ & $\mathrm{Cl}$ & $\mathrm{K}_{2} \mathrm{O}$ \\
\hline d-glaze jar no. 7 & 8.2 & 32.3 & - & - & 2.3 & 57.3 & - & - & - & - \\
\hline e-corrosion crust & 4.4 & 12.5 & 9 & 5.8 & 3.0 & 41.2 & 19.0 & 4.0 & - & 1.1 \\
\hline $\mathrm{f}$-corrosion product & 5.8 & 30.8 & 0.9 & - & 8.2 & 44.9 & - & 6.9 & 1.9 & 0.6 \\
\hline g-corrosion in crack & 8.6 & 29.7 & 2.4 & - & 2.9 & 42.3 & - & 5.7 & 7.3 & 1.1 \\
\hline
\end{tabular}

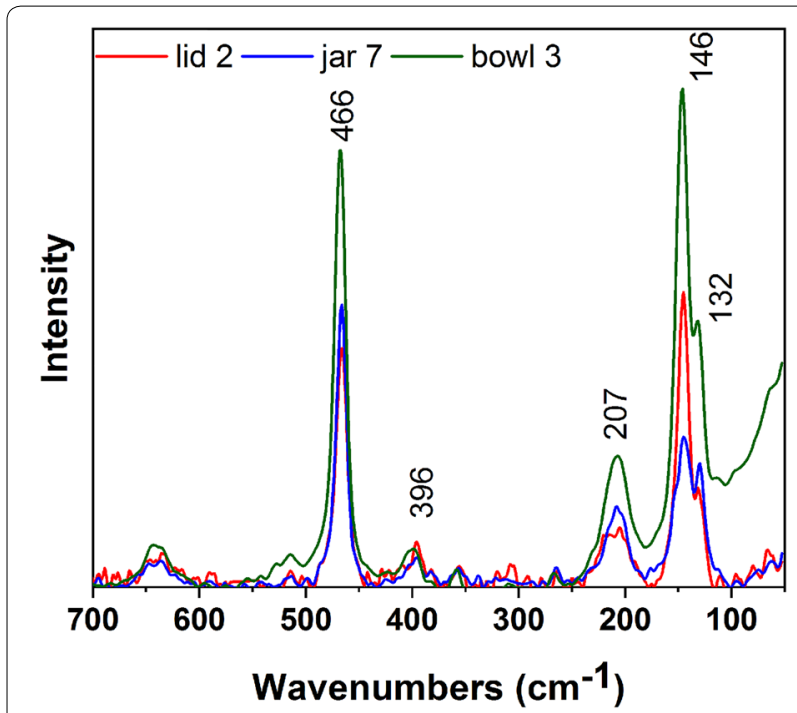

Fig. 11 Raman spectra of grains in the green glazes of vessel nos. 2, 3 and 7

\section{Conclusion}

Forty ceramic bodies and glazes from three hundred years of ceramic production were examined. This study analysed items of ordinary ceramic kitchenware, comprising chiefly cooking pots and tripod cooking vessels. However, the analysed set also included several items of tableware in the form of shallow painted bowls, one flowerpot, and one three-legged bowl glazed on both sides. As far as the representation of individual shapes is concerned, the assemblage is standard and corresponds to the ceramic finds dating to the Modern Age urban environment in the Czech lands. In general, it applies that most ceramic assemblages are dominated by barrel-shaped pots glazed only on the inner side. Deep bowls and cooking vessels make up only a single-digit percentage of discoveries. Tableware is represented by jugs and shallow bowls. Other forms of ceramics are usually represented by random solitary pieces. On the case of Prague, it is possible to compare

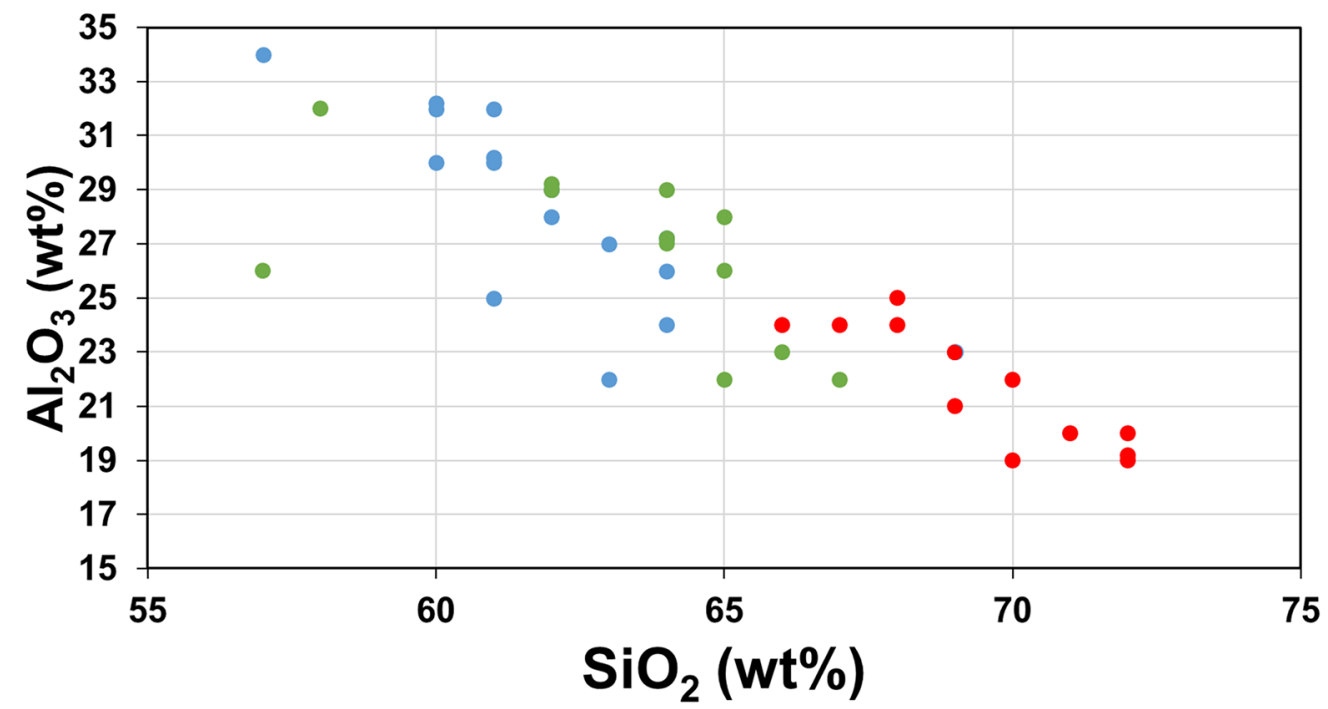

Fig. 12 Binary diagram $\mathrm{SiO}_{2}-\mathrm{Al}_{2} \mathrm{O}_{3}$ of the ceramic bodies of finds grouped by the dating of the finds; some samples overlap (red-the second half of the 15th century to the first half of the 16th century, green-the second half of the 16th century to the first half of the 17th century, blue-the second half of the 17th century to the first half of the 18th century) 


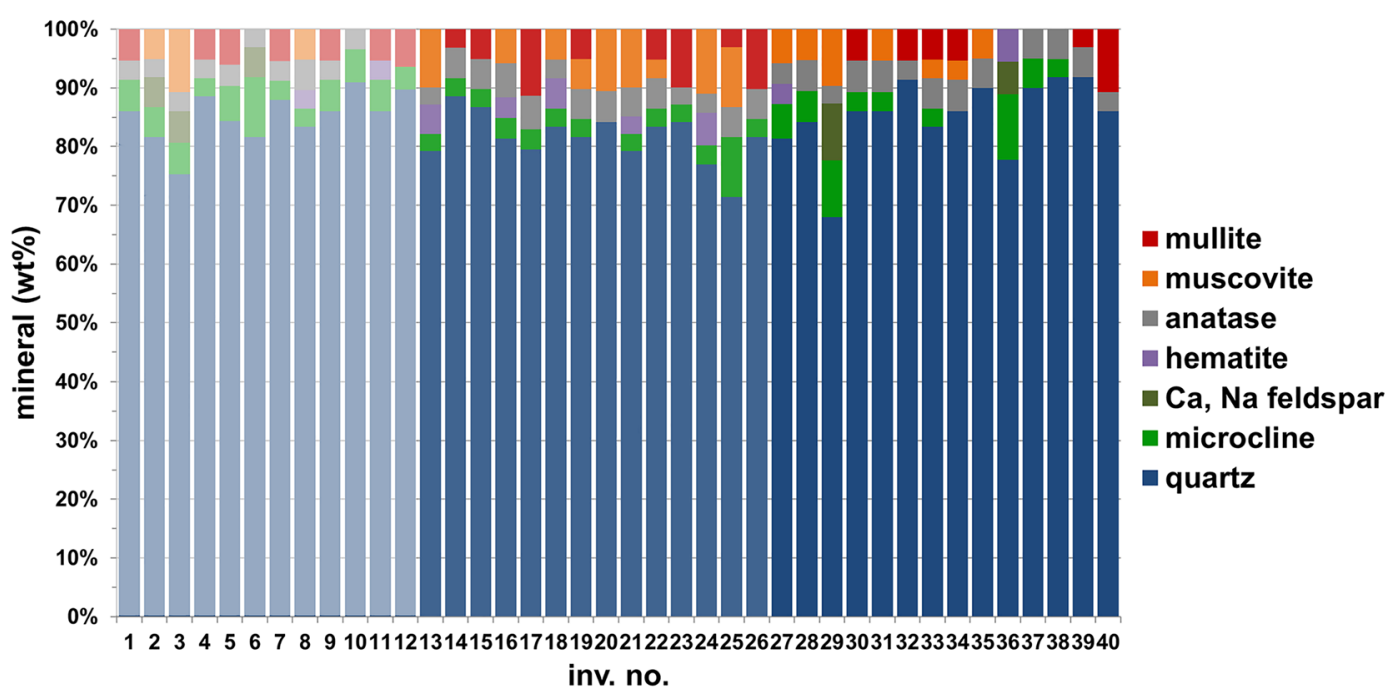

Fig. 13 Semi-quantitative mineralogical composition of the ceramic bodies of finds determined by XRD-the colour intensity corresponds to the dating of finds (nos. 1-12 are from the second half of the 15th century to the first half of the 16th century; nos. 13-26 are from the second half of the 16th century to the first half of the 17th century, and nos. 27-40 are from the second half of the 17th century to the first half of the 18th century)

finds from Republic Square (Náměstí Republiky) in Prague's Old Town [67], from the Theatine Palace in Lesser Town [68] and the waste pit in Prague's New Town [29]. Similar conclusions have also been reached during a comparison of the ceramic assortment found in South Bohemia [69]. In this particular assemblage of found artefacts, a unique position is held by three vessels associated with technical/chemical ceramics. They are exceptional particularly with regard to the condition in which they have been preserved. These types of items appear rarely in archaeological find assemblages and, as a rule, are usually in fragments. It was proved that the studied vessels were manufactured from similar raw materials free of calcite admixtures. The ceramic materials were tempered mostly by quartz. The results of chemical and mineralogical analyses of the ceramic bodies showed that the raw materials that were used did not significantly change from the 15 th to the 18 th centuries. Differences were observed only in the group of the oldest vessels, with a clay matrix containing very poorly sorted inclusions. The grain size distribution was significantly bimodal. Most of the samples from the second and third group did not contain large inclusions, and some contained more mica in the matrix. The orientation of all the samples showed the vessels were produced by rotation. The firing temperatures were in the range of about $850-1050{ }^{\circ} \mathrm{C}$. The range is determined by the degree of the dehydroxylation of mica, the "optical activity" or "inactivity" of the matrix, and the absence or presence of mullite. In the case of the glazes, it was proved that the studied samples were medium- or high-lead content glazes without any significant differences over the centuries. The distinction between the oldest vessels (dating to 1450-1550) and the younger ones is probably due to an incident in 1541, when a large fire occurred at the site of the findings (Prague's Hradčany district). Because of the fire, it is possible that a large quantity of utility ceramics were replaced in Hradčany households In the second period (1550-1650), the ceramic craft significantly developed and a substantial number of kitchen vessels were replaced by newly manufactured items. During the Thirty Years' War and the subsequent period (16501750 ), it can be assumed that the production processes from the time of the development of the craft were preserved. This is probably the reason for the similarity of the vessels from the second and third groups and their difference from the vessels from the first-oldestgroup. In the case of the glazes, it was proved that the studied samples were medium- or high-lead content glazes, again without any significant differences over the centuries. Three technical ceramic vessels showed a similar type of ceramic body and glaze. Based on the results of the performed analyses, we may assume that these vessels were made from similar raw materials in the same workshop and that they were part of one distillation apparatus. All three vessels show pronounced degradation caused by their usage and their subsequent preservation in a waste pit. The vessels had to sustain contact with hot and rather acidic liquids, which is a 


\begin{tabular}{|c|c|c|c|c|c|c|}
\hline Object after restoration & $\begin{array}{l}\text { Inv. } \\
\text { No. }\end{array}$ & Glaze colour & $\begin{array}{c}\text { Colouring/ } \\
\text { opacifying } \\
\text { agent }\end{array}$ & $\begin{array}{l}\text { Identified } \\
\text { defect }\end{array}$ & Corrosion product & $\begin{array}{l}\text { Ceramic body } \\
\text { colour }\end{array}$ \\
\hline & 1 & & $\begin{array}{c}\mathrm{Fe}_{2} \mathbf{O}_{3}, \mathbf{S b}_{2} \mathbf{O}_{3}, \\
\mathrm{CuO} / \mathbf{Z n O}\end{array}$ & unidentified & unidentified & \\
\hline & 2 & & $\begin{array}{l}\mathrm{CuO}, \mathrm{Fe}_{2} \mathrm{O}_{3} \\
\mathrm{Sb}_{2} \mathrm{O}_{3} / \mathrm{TiO}_{2}\end{array}$ & $\begin{array}{l}\text { delayed } \\
\text { crazing }\end{array}$ & $\begin{array}{c}\text { Calcium Lead } \\
\text { Phosphate Hydroxide } \\
\mathrm{Ca}_{5.5} \mathrm{~Pb}_{4.5}\left(\mathrm{PO}_{4}\right)_{6}(\mathrm{OH})_{2}\end{array}$ & \\
\hline & 3 & & $\begin{array}{l}\mathrm{CuO}, \mathrm{Fe}_{2} \mathrm{O}_{3}, \\
\mathrm{Sb}_{2} \mathrm{O}_{3}, \mathrm{SnO}_{2}\end{array}$ & $\begin{array}{l}\text { delayed } \\
\text { crazing }\end{array}$ & $\begin{array}{l}\text { Lead Sulphate } \\
\mathrm{Pb}\left(\mathrm{SO}_{4}\right)\end{array}$ & \\
\hline & 4 & & $\begin{array}{c}\mathrm{Fe}_{2} \mathrm{O}_{3}, \mathrm{Sb}_{2} \mathrm{O}_{3}, \\
\mathrm{CuO} / \mathrm{CaO}\end{array}$ & unidentified & unidentified & \\
\hline & 5 & & $\begin{array}{c}\mathrm{Fe}_{2} \mathbf{O}_{3}, \mathrm{Sb}_{2} \mathrm{O}_{3} \\
\mathrm{CuO} / \mathrm{ZnO}\end{array}$ & unidentified & unidentified & \\
\hline & 6 & & $\begin{array}{c}\mathrm{Fe}_{2} \mathbf{O}_{3}, \mathrm{Sb}_{2} \mathrm{O}_{3} \\
\mathrm{CuOO} / \mathbf{Z n O}\end{array}$ & unidentified & unidentified & \\
\hline & 7 & & $\begin{array}{c}\mathrm{CuO}, \mathrm{Fe}_{2} \mathrm{O}_{3} \\
\mathrm{Sb}_{2} \mathrm{O}_{3}\end{array}$ & $\begin{array}{l}\text { corrosion } \\
\text { crust }\end{array}$ & $\begin{array}{c}\text { Calcium Lead } \\
\mathrm{Phosphate} \mathrm{Chloride} \\
\mathrm{Ca}_{2} \mathrm{~Pb}_{3}\left(\mathrm{PO}_{4}\right)_{3} \mathrm{Cl} \\
\text { Calcium Phosphate } \\
\text { Hydroxide Hydrate } \\
\mathrm{CaPO}_{3}(\mathrm{OH}) \cdot 2 \mathrm{H}_{2} \mathrm{O}\end{array}$ & \\
\hline & 8 & & $\begin{array}{c}\mathrm{Fe}_{2} \mathrm{O}_{3}, \mathrm{Sb}_{2} \mathrm{O}_{3} \\
\mathrm{CuO} / \mathrm{ZnO}\end{array}$ & $\begin{array}{l}\text { instant } \\
\text { crazing }\end{array}$ & unidentified & \\
\hline & 9 & & $\begin{array}{c}\mathrm{Fe}_{2} \mathrm{O}_{3}, \mathrm{Sb}_{2} \mathrm{O}_{3} \\
\mathrm{CuO}\end{array}$ & $\begin{array}{l}\text { corrosion } \\
\text { crust }\end{array}$ & $\begin{array}{c}\text { Calcium Lead } \\
\text { Phosphate Chloride } \\
\mathrm{Ca}_{2} \mathrm{~Pb}_{3}\left(\mathrm{PO}_{4}\right)_{3} \mathrm{Cl} \\
\text { Calcium Sulphate } \\
\mathrm{CaSO}_{4}\end{array}$ & \\
\hline & 10 & & $\mathrm{CuO}, \mathrm{Fe}_{2} \mathrm{O}_{3}$ & unidentified & unidentified & \\
\hline & 11 & & $\mathrm{Fe}_{2} \mathrm{O}_{3}, \mathrm{CuO}$ & unidentified & unidentified & \\
\hline & 12 & & $\begin{array}{c}\mathrm{CuO}, \mathrm{Fe}_{2} \mathrm{O}_{3} \\
\mathrm{Sb}_{2} \mathrm{O}_{3} / \mathrm{SnO}_{2}\end{array}$ & unidentified & unidentified & \\
\hline
\end{tabular}

Fig. 14 Identification of glaze colourants and a characterization of their deterioration 


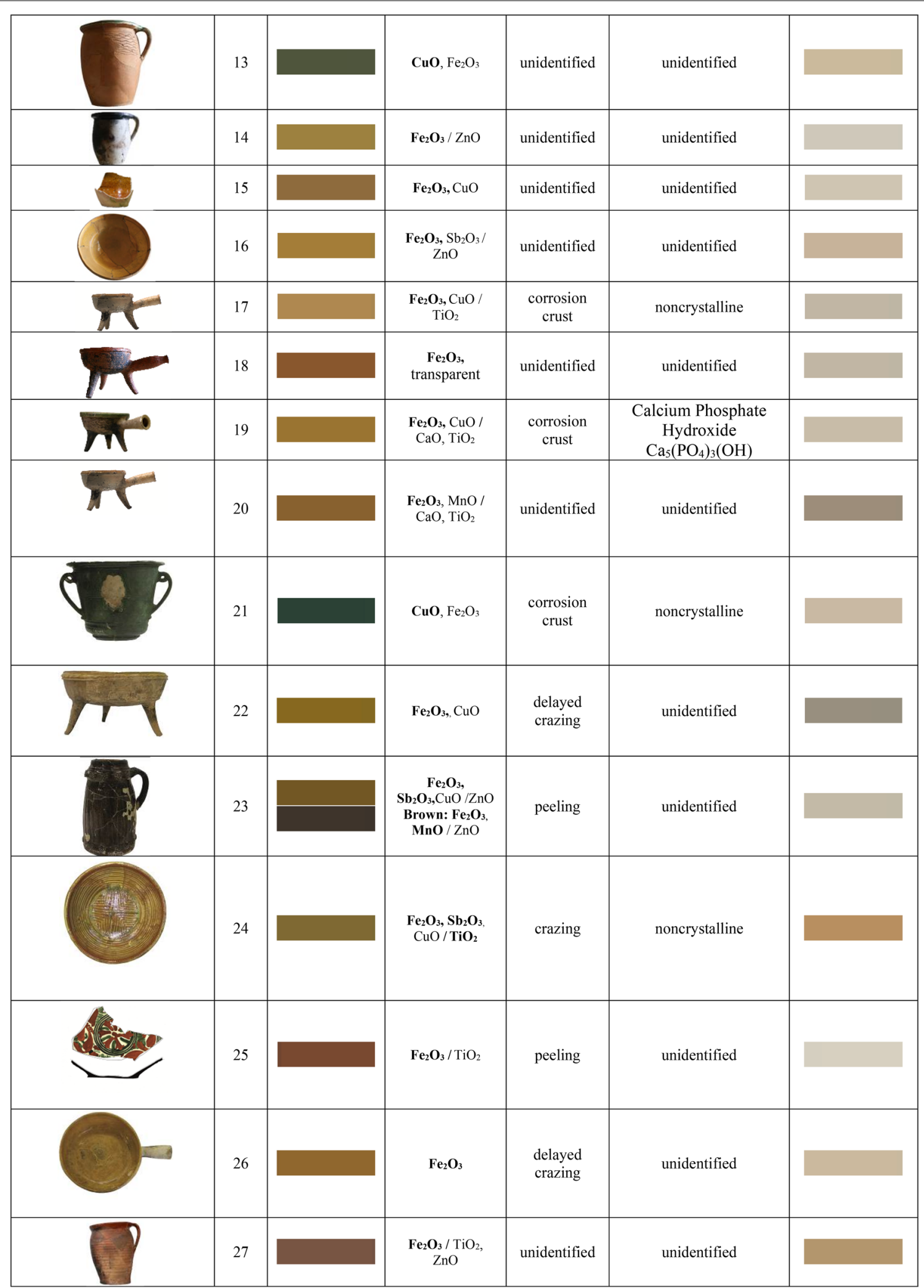

Fig. 14 continued 


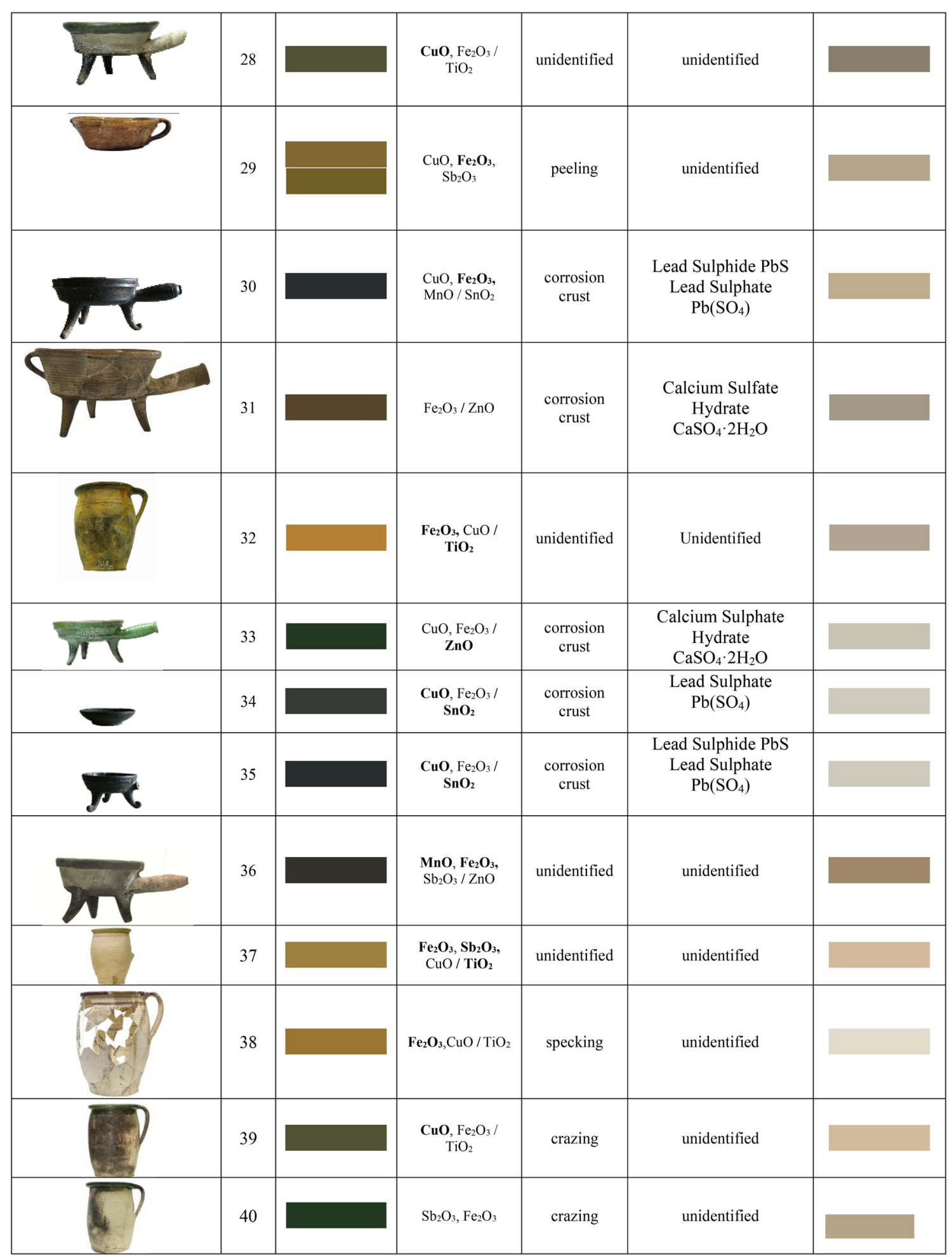

Fig. 14 continued 
relatively aggressive environment for this type of material. It is now a well-known fact that lead glazes have relatively low resistance in acidic environments, causing the toxic $\mathrm{Pb}$ component to leach into the stored liquids. Most of the identified corrosion products $\mathrm{Ca}$ and $\mathrm{Pb}$ phosphates) are typical of the waste-containing environment.

\section{Abbreviations}

T: Transparent; SC: Semi-covering; FC: Full covering; XRF: X-ray fluorescence; WD-XRF: Wavelength dispersive X-ray fluorescence; PCA: Principal component analysis; XRD: X-ray diffraction; RIR: Reference intensity ratio; PDF: Powder diffraction file; CIE: International commission on illumination; OM: Optical microscopy; SEM: Scanning electron microscopy; EDX: Energy dispersive X-ray analysis; STA: Simultaneous thermal analysis; TG: Thermogravimetric analysis; DTA: Differential thermal analysis; RT: Room temperature.

\section{Acknowledgements}

Not applicable.

\section{Authors' contributions}

AK interpreted the data and was a major contributor in writing the manuscript. MK and MK made significant contributions to the content, reviewed the whole text and made valuable comments and suggestions. They also performed and interpreted the X-ray and thermal analyses. GB selected the archaeological finds and contributed the archaeological background. RS performed the Raman spectroscopy measurements and contributed to the interpretation of the analytical data and the preparation of the draft of the study. PD and MBK prepared the samples and contributed to the analytical works. All authors read and approved the final manuscript.

\section{Funding}

This work was financially supported by the project of the Ministry of Culture of the Czech Republic: Technology of Treatment and Identification of Degradation Processes of Ceramic Finds from Hradčany Palaces-Methods of Restoration and Conservation of Porous and Dense Ceramics and Porcelain (NAKI II DG18P02OVV28).

\section{Availability of data and materials}

The datasets used and/or analyses results obtained in the current study are available from the corresponding author on request.

\section{Competing interests}

The authors declare that they have no competing interests.

\section{Author details}

1 Department of Glass and Ceramics, University of Chemistry and Technology Prague, Technická 5, 16628 Prague, Czech Republic. ${ }^{2}$ Central Laboratories, University of Chemistry and Technology Praque, Technická 5, 16628 Prague, Czech Republic. ${ }^{3}$ Institute of Archaeology of the Czech Academy of Sciences, Prague, v. v. i., Letenská 4, Prague 1, Czech Republic. ${ }^{4}$ National Gallery Prague, Staroměstské nám. 12, 11015 Prague, Czech Republic.

Received: 3 March 2020 Accepted: 23 July 2020

Published online: 12 August 2020

\section{References}

1. Gaimster DRM. The Historical Archaeology of Pottery Supply and Demand in the Lower Rhineland AD 1400-1800. BAR International Series 1518, Studies in Contemporary and Historical Archaeology 1. Oxford: British Archaeological Reports; 2006.

2. Kluttig-Altmann R. Von der Drehscheibe bis zum Scherbenhaufen. Leipziger Keramik des 14. bis 18. Jahrhunderts im Spannungsfeld von Herstellung, Gebrauch und Entsorgung. Archäologische Informationen. 2007; 28(1-2):227-232. doi: 0.11588/ai.2005.1\&2.12588.
3. Lange D. Frühneuzeitliche Keramik aus dem ehemaligen Benediktinerkloster Chemnitz. Dissertation: Eberhard-Karls-Universität Tübingen; 1996.

4. Scheidemantel D, Schifer T. Waldenburger Steinzeug, Archäologie und Naturwissenschaften: Veröffentlichungen des Landesamtes für Archäologie mit Landesmuseum für Vorgeschichte. 1st ed. Dresden: Landesamt $f$ Archäol Sachsen; 2005.

5. Stephan HG. Keramik der Renaissance im Oberweserraum und an der unteren Werra. Beiträge der Archäologie zur Erforschung der Sachkultur der frühen Neuzeit. In: Janssen W, Steuer H, Binding G, editors. Zeitschrift für Archäologie des Mittelalters. Beiheft 7 Bonn: Dr. Rudolf Habelt; 1992.

6. Kaltenberger A. Keramik des Mittelalters und der Neuzeit in Oberösterreich: vol. 1. Gmünd: Bibliothek der Provinz; 2009.

7. Kraschitz J. Zwei datierte frühneuzeitliche Fundkomplexe aus Graz. Fundberichte aus Österreich. 2003;42:205-79.

8. Krenn M. Koch- und Tafelgeschirr des 18. Jahrhunderts, Ein Keramikfundkomplex aus Melk, Niederösterreich. Vienna: Berger; 2007.

9. Frascoli L, Hartmann D, Windler R, Gygax M. Handwerker- und Kaufmannhaushalte im frühneuzeitlichen Winterthur. Monographien der Kantonsarchäologie Zürich. 1st ed. Zürich: Fotorotar AG; 1997.

10. Heege A, Kistler A. Keramik aus Langnau: zur Geschichte der bedeutendsten Landhafnerei im Kanton Bern. Bern: Verlag Bernisches Historisches Museum; 2017.

11. Keller C. Gefässkeramik aus Basel. Untersuchungen zur spätmittelalterlichen und frühneuzeitlichen Gefässkeramik aus Basel, Typologie-Technologie-Funktion-Handwerk. Basel: Archäologische Bodenforschung des Kantons Basel-Stadt; 1999.

12. Buzas G, Laszlovszky J. The medieval royal Palace at Visegrád. Budapest: Archaeolingua; 2013.

13. Starski M. Post-medieval Pottery from Small Townships of Gdansk Pomerania. A Preliminary Evaluation. In: Blazkova G, Matekova K, editors. Europa Postmedieavalis 1. Prague: Archeologicky ustav AV CR, Praha, v. v. i.; 2019. p. 141-152.

14. Bis M. The White Pottery in Early Modern Poland: Local Production or Regional Fashion? In: Blazkova G, Matejkova K, editors. Europa Postmedieavalis 1. Prague: Archeologicky ustav AV CR, Praha, v. v. i.; 2019. p. $141-152$.

15. Sachan A, Penumadu D. Identification of microfabric of kaolinite clay mineral using X-ray diffraction technique. Geotech Geol Eng. 2007;25:603-16.

16. Holakooei P, et al. A new look at XRD patterns of archaeological ceramic bodies. An assessment for the firing temperature of 17 th century haft rang tiles from Iran. J Therm Anal Calorim. 2014;118:165-76.

17. Nuevo MJ, Martín Sánchez A. Application of XRF spectrometry to the study of pigments in glazed ceramic pots. Appl Radiat Isotopes. 2011;3:574-9.

18. Emani M. QXRD, XRF and optical microscopy applied to characterization and provenance of ancient ceramics from Haft Teppeh (1500-1150 BC), southwest Iran. Mat Sci Eng. 2012;37:1-8.

19. Papachristodoulou $C$, et al. A study of ancient pottery by means of $X$-ray fluorescence spectroscopy, multivariate statistics and mineralogical analysis. Anal Chim Acta. 2006;573:347-53.

20. Pradell T, Molina G, Molera J, Pla J, Labrador A. The use of micro-XRD for the study of glaze color decorations. Appl Phys A. 2013;111(1):121-7. https://doi.org/10.1007/s00339-012-7445-x.

21. Papadopoulou DN, et al. Thermal and mineralogical contribution to the ancient ceramics and natural clays characterization. J Therm Anal Calorim. 2006;84(1):39-45.

22. Földvári M. Handbook of thermogravimetric system of minerals and its use in geological practice. Budapest: Geological Institute of Hungary; 2011.

23. Palanivel R, Meyvel S. Microstructural and microanalytical study-(SEM) of archaeological pottery artefacts. Rom J Phys. 2010;55(3-4):333-4.

24. Kopar T, Ducman V. Low-vacuum SEM analyses of ceramic tiles with emphasis on glaze defects characterisation. Mater Charact. 2007;58:11337. https://doi.org/10.1016/j.matchar.2007.04.022.

25. Colomban P, Milande V, Milande L. On-site Raman analysis of Iznik pottery glazes and pigments. J Raman Spectrosc. 2004;35(7):527-35. https://doi. org/10.1002/jrs.1163.

26. Sandalinas C, Ruiz-Moreno S, López-Gil A, Miralles J. Experimental confirmation by Raman spectroscopy of a Pb-Sn-Sb triple oxide yellow pigment in sixteenth-century Italian pottery. J Raman Spectroscopy. 2006;37:1146-53. 
27. Šefců R, Chlumská S, Hostašová A. An investigation of the lead tin yellows type I and II and their use in Bohemian panel paintings from the Gothic period. Herit Sci. 2015;3:16. https://doi.org/10.1186/s40494-015-0045-2.

28. Blazkova G. Rane novoveke odpadni jimky na Prazskem hrade. Analyza nalezovych souboru-Early modern waste pits at Prague Castle. An analysis of find assemblages, In: Blažková G, editor. Castrum Pragense. Prague: Archeologicky ustav AV CR, Praha, v. v. i.; 2016. p. 61-184.

29. CymbalakT, Matějková K. Zpracovani nalezu ze dvou odpadnich jimek a uskali jejich interpretace-analysis from two cesspits and problems with their interpretation. Staleta Praha. 2012;28(2):41-76.

30. Frolik J, Musil J. Zachranny archeologicky vyzkum v Hradebni ulici v Chrudimi v roce 2006. Chrudimský vlastivedny sbornik. 2010;14:3-28.

31. Klapste J. Archeologie středověkého domu v Moste (čp. 226)-The archaeology of a medieval House (No. 226) in Most. Prague: Mediaevalia Archaeologica 4; 2002.

32. Krajic R. Voda a odpady jako privatni i komunalni problem mestskych aglomeraci. Doklady z mesta Tabora od 13. do 18. Stoleti-Wasser und Abfall als privates und kommunales Problem städtischer Agglomerationen. Belege aus der Stadt Tabor, 13.-18. Jahrhundert, Pamatky archeologicke. 2009; 100: 261-300.

33. Merinsky Z, Prochazka R. K nekterym aspektum kazdodenniho a svatecniho zivota stredovekeho cloveka na Morave a ve Slezsku. Archaeologia Historica. 2010;35(1-2):7-44.

34. Hiesserle from Chodaw, Illustration of Prague Castle from the journal of Heindrich Hiesserle from Chodaw. The Prague Uprising of 15 February 1611, from 1612 to 1630. National museum, sig. VI A 12, Fol. 74b.

35. Brunswig H. Liber de arte distillandi de compositis. Johann Grüninger, Bavaria: 1512.

36. Blazková G, Zegklitz J. Současný stav poznani rane novoveke keramiky v Praze. In: Bohacova I, Smolikova M, editors. Praha archeologicka, Archaeologica Pragensia-Supplementum 3. Prague: Muzeum hlavniho mesta Prahy; 2016. p. 147-78.

37. Panek J. Italove, Nizozemci a Nemci v rudolfinske Praze-nektere formy a problemy souziti. Documenta Pragensia. 2001;19:67-74.

38. Bundszus M. Renaissancezeitliche Keramik von der Wasserburg Göltzsch in Rodewisch im Vogt-land. In: Krabath S, editor. Keramik in Mitteldeutschland. Stand der Forschung und Perspektiven. Veröffentlichungen des Landesamtes für Archäologie. Dresden: Landesamt für Archäologie; 2012. p. 245-258.

39. Durdik T. Nekolik poznamek k ceske hradni kazdodennosti-Einige Anmerkungen zum böhmi-schen Burgalltag. Archaeologia Historica. 2010;35:45-62.

40. Moorhouse S. Medieval distilling-apparatus of glass and pottery. Mediev Archaeol. 1972;16:79-121. https://doi.org/10.1080/00766097.1972.11735 348.

41. Osten von S. Das Alchemistenlaboratorium Oberstockstall. Ein Fundkomplex des 16. Jahrhunderts aus Niederösterreich. Monographien zur Frühgeschichte und Mittelalterarchäologie. Innsbruck: Universitätsverlag Wagner; 1998.

42. Unger J. Život na lelekovickém hradě ve 14. století. Antropologická sociokulturní studie. Brno: Nadace Universitas Masarykiana; 1999.

43. Codex G15, sing. Code 22, deposited in Prague Castle Archive, p. 115-116.

44. Bohacová I, Frolik J, Chotebor P, Zegklitz J. Byvaly dum biskupuv na Prazskem hrade-Das ehemalige Bischofshaus auf der Prager Burg. Archaeologia Historica. 1986;11:119.

45. Blazkova G, Veprekova J. Nalezy hmotne kultury z renesancnich odpadnach jimek z Prazskeho hradu, Katalog-Material Finds from the Renaissance Waste pits at Prague Castle, Catalogue, Castrum Pragense. Prague: Archeologicky ustav AV CR, Praha, v. v. i.; 2015.

46. Dairy Hrad prazsky-III. nadvori. Dennik vykopavek/4. VI.-27.VII/. Der Handschrift hinterlegt im Archäologischen Institut der Akademie der Wissenschaften, Prag, die Abteilung Prager Burg. 1925.

47. Dairy Zpracovani keramickeho materialu na Prazskem hrade. Rucne psany. Ulozen v Archeologickem ustavu AV CR, Praha, v. v. i., pracoviste Prazsky hrad. 1926-1927.

48. Dairy Hrad Prazsky. Dennik o konservovani nadob, vykopaných na Prazskem hrade. 1927-1929/26. XI.-21.IV./.1927-1930.

49. Dairy Dennik konservovani nadob 1930-1938 26.XI.-21.IV. Ulozen $\checkmark$ Archeologickem ustavu AV CR, Praha, v. v. i., pracoviste Prazsky hrad. 1930-1938.
50. Klouzkova A, Kohoutkova M, Blazkova G, Zemenova P, Kavanova M. Results and evaluation of chemical-technological analyses of glazes on early modern pottery. In: Blazkova G, editor. Castrum Pragense. Prague: Archeologicky ustav AV CR, Praha, v. v. i.; 2016. p. 205-237.

51. Nyakairu GWA, Kurzweil H, Koeberl C. Mineralogical, geochemical, and sedimentological characteristics of clay deposits from central Uganda and their applications. J Afr Earth Sci. 2002;35(1):123-34. https://doi. org/10.1016/S0899-5362(01)00077-X.

52. Rosen OM, Abbyasov AA, Tipper JC. MINLITH-an experience based algorithm for estimating the likely mineralogical compositions of sedimentary rocks from bulk chemical analyses. Comput Geosci UK. 2004;30:647-61. https://doi.org/10.1016/j.cageo.2004.03.011.

53. Schneider H, Komarneni S. Mullite. Weinheim: Wiley-VCH Verlag GmbH a Co. KGaA; 2004. p. 168.

54. K Kloužková A, Kavanová M, Kohoutková M, Zemenová P, Dragoun Z. Identification of causes of degradation of Gothic ceramic tiles by thermal analyses. J Therm Anal Calorim. 2016;125(3):1311-8. https://doi. org/10.1007/s10973-016-5488-5.

55. Reedy C. Thin-section petrography of stone and ceramic cultural materials. London: Archetype Books; 2008.

56. Klouzkova A, Zemenova P, Kohoutkova M, Mazac Z. Ageing of fired-clay ceramics: comparative study of rehydroxylation processes in a kaolinitic raw material and moon-shaped ceramic idol from the Bronze Age. Appl Clay Sci. 2016;119(2):358-64. https://doi.org/10.1016/j.clay.2015.11.002.

57. Zemenova P, Klouzkova A, Kohoutkova M, Kral R. Investigation of the first and second dehydroxylation of kaolinite. J Therm Anal Calorim. 2014;116:633-9. https://doi.org/10.1007/s10973-014-3748-9.

58. Kloužková A, Šefců R, Turková I, Kolářová M, Bajeux Kmoníčková M, Dvořáková P. Multi-Instrumental characterization of decorative layers in glazed ceramics reliefs from the Schwarzenbergr palace in Prague. Ceramics-Silikáty. 2019;63(4):449-59. https://doi.org/10.13168/ cs.2019.0041.

59. Neri E, Morvan C, Colomban P, Guerra MF, Prigent V. Late Roman and Byzantine mosaic opaque "glass-ceramics" tesserae (5th-9th century). Ceram Int. 2016;42(16):18859-69. https://doi.org/10.1016/j.ceramint.2016.09.033.

60. Kharbish S, Jeleň S. Raman spectroscopy of the Pb-Sb sulfosalts minerals: boulangerite, jamesonite, robinsonite and zinkenite. Vib Spectrosc. 2016;85:157-66. https://doi.org/10.1016/j.vibspec.2016.04.016.

61. Vieira Ferreira LF, Varela Gomes R, Pereira MFC, Santos LF, Ferreira Machado I. Islamic ceramics in Portugal found at Silves Castle (8th to 13th c.): an archaeometric characterization. J Archaeol Sci Rep. 2016;8:434-43. https://doi.org/10.1016/j.jasrep.2016.06.051.

62. Taylor JR, Bull AC. Ceramics glaze technology. 2nd ed. Oxford: Pergamon Press; 1986

63. Klouzkova A, Zemenova P, Kohoutkova M, Klouzek J. Hydrothermal rehydroxylation of kaolinite studied by thermal analysis. Ceramics Silikáty. 2013;57(4):342-7.

64. Angeli $F$, Jollivet $P$, Charpentier T, Fournier M, Gin S. Structure and chemical durability of lead crystal glass. Environ Sci Technol. 2016;50(21):1154958. https://doi.org/10.1021/acs.est.6b02971.

65. Wang PW, Zhang L. Structural role of lead in lead silicate glasses derived from XPS spectra. J Non-Cryst Solids. 1996;194(1-2):129-34. https://doi. org/10.1016/0022-3093(95)00471-8.

66. Rahimi RA, Sadrnezhaad SK, Raisali G. Chemical durability of lead silicate glass in $\mathrm{HNO}_{3}, \mathrm{HCl}$ and $\mathrm{H}_{2} \mathrm{SO} 4$ aqueous acid solutions. J Non-Cryst Solids. 2009;355(3):169-74. https://doi.org/10.1016/j.jnoncrysol.2008.11.001.

67. Vařeka P. Pohled do kuchyně a na jídelní stưl-výpověd' keramických nálezů. In: Juřina P, et al., editors. Náměstí republiky. Výzkum století, Prague: Archaia; 2009. p. 153-62.

68. Čiháková J, Müller M. Hygienické zázemí koleje theatinů v Thunovské ulici na Malé Straně-Hygienic facilities of the Theatine College in Thunovská Street at Malá Strana. Staletá Praha. 2013;29(2):120-84.

69. Čapek L, Preusz M. Changes in pottery production, distribution and consumption in the post-medieval period in South Bohemia. In: Blažková G, Matějková K, editors. Europa Postmedieavalis 1. Oxford: Archaeopress; 2019. p. 33-52.

\section{Publisher's Note}

Springer Nature remains neutral with regard to jurisdictional claims in published maps and institutional affiliations. 